NBER WORKING PAPER SERIES

\title{
CHOOSING ELECTORAL RULES: THEORY AND EVIDENCE FROM US CITIES
}

\author{
Philippe Aghion \\ Alberto Alesina \\ Francesco Trebbi \\ Working Paper 11236 \\ http://www.nber.org/papers/w11236
NATIONAL BUREAU OF ECONOMIC RESEARCH
1050 Massachusetts Avenue
Cambridge, MA 02138
March 2005

We thank Matilde Bombardini, Gary Chamberlain, John Friedman, Edward Glaeser, Richard Holden, Caroline Hoxby, David Lucca, James Robinson, and John Wallis for useful comments and suggestions. We are grateful to participants of the CIAR meetings in Toronto and seminars at Harvard University. Dilyan Donchev, Laura Serban, and Radu Tatucu provided excellent research assistance. Trebbi acknowledges financial support from the Social Sciences Research Council. The views expressed herein are those of the author(s) and do not necessarily reflect the views of the National Bureau of Economic Research.

(C2005 by Philppe Aghion, Alberto Alesina, and Francesco Trebbi. All rights reserved. Short sections of text, not to exceed two paragraphs, may be quoted without explicit permission provided that full credit, including (C) notice, is given to the source. 
Choosing Electoral Rules: Theory and Evidence from US Cities

Philppe Aghion, Alberto Alesina, and Francesco Trebbi

NBER Working Paper No. 11236

March 2005

JEL No. H0

\begin{abstract}
This paper studies the choice of electoral rules, in particular, the question of minority representation. Majorities tend to disenfranchise minorities through strategic manipulation of electoral rules. With the aim of explaining changes in electoral rules adopted by US cities (particularly in the South), we show why majorities tend to adopt "winner-take-all" city-wide rules (at-large elections) in response to an increase in the size of the minority when the minority they are facing is relatively small. In this case, for the majority it is more effective to leverage on its sheer size instead of risking to concede representation to voters from minority-elected districts. However, as the minority becomes larger (closer to a fifty-fifty split), the possibility of losing the whole city induces the majority to prefer minority votes to be confined in minority-packed districts. Single-member district rules serve this purpose. We show empirical results consistent with these implications of the model.

\author{
Philippe Aghion \\ Department of Economics \\ University College London \\ Gower Street \\ London, WC1 6BT \\ and NBER \\ p_aghion@harvard.edu
}

\author{
Alberto Alesina \\ Department of Economics \\ Harvard University \\ Cambridge, MA 02138 \\ and NBER \\ aalesina@harvard.edu \\ Francesco Trebbi \\ Department of Economics \\ Harvard University \\ Cambridge, MA 02138 \\ trebbi@fas.harvard.edu
}




\section{Introduction}

One of the key questions in political economy is how different electoral laws affect policy outcomes. In order to provide an answer several authors take electoral rules as exogenous or predetermined and use them as explanatory variables for various policies ${ }^{1}$. However, the rules of government are themselves endogenous variables chosen at constitutional tables. Ideally, rules should be chosen behind a "veil of ignorance", that is decisions should be taken as if one ignored the identity of those benefiting from the choices themselves. In reality, however, in most constitutional tables the veil of ignorance is "see-through", in the sense that there is some knowledge of who would benefit under alternative rules and of what policy outcomes those rules would produce. Therefore the "exogeneity" of constitutions can be called into question.

Our focus is on the question of minority representation, with special reference to the nature of electoral districts and alternative rules for the choice of representatives. We have two goals in mind, one more general and one more specific. The first and more general point is to make progress in modeling institutional choice as endogenous. On the first point, most of the literature is normative, i.e. it discusses how electoral laws should be chosen, starting from the work of Hayek (1960) and Buchanan and Tullock (1962)2. A normative approach usually characterizes works in Political Science, with some notable exception such as Riker (1986) and several essays in Colomer (2004).Economists have only recently began to pay attention to the endogeneity of political insti-

\footnotetext{
${ }^{1}$ A classic study is Lijphart (1994). The most recent contributions on the effects of institutions (taken as exogenous or prestermined) on economic policies are Persson and Tabellini (2003) for a sample of democratic countries and Baqir (2003) for a cross-section of US cities. They build upon a vast literature on the effects of alternative forms of government on policies, a literature that we do not review here. We refer the reader to Persson and Tabellini (2003) for a survey of the cross-country literature. On US states see in particular Alt and Lowry (1994), Poterba (1994), and Bohn and Inman (1996) amongst others. Mulligan and Sala I Martin (2004) offer a dissenting view, namely that policies are determined by lobbying pressure that are not much affected by institutional forms of government.

${ }^{2}$ For a survey of the literature on Constitutional Theory, see Voigt (1997).
} 
tutions from a positive, as opposed to a normative perspective. Alesina and Glaeser (2004) for instance discuss how the choice of alternative electoral rules, which are themselves associated with different policy choices over the welfare state, are indeed the result of strategic constitutional choices. The present paper is a study in "positive constitutional theory", with a special emphasis on the question of how majorities select electoral rules to partially disenfranchise minorities.

The second and more specific goal of our paper is to analyze the evolution of minority representation in American cities. We examine empirical evidence drawn from US municipalities, that adopt two types of electoral rules: either a single-member district (also called single-district) or at-large rules (or a combination of the two). Councilmen elected by district compete for one or, more rarely, multiple seats in each geographic subdivision (district or ward) of the city. Differently, in at-large elections, officials are elected in multi-member plurality districts, voters have as many votes as there are council seats, and the only multi-member district is identified by the city itself. The basic "winnertake-all" logic holds for both rules. For given council size, the difference between single-district and at-large rules is due to geographic clustering of groups of voters with homogeneous preferences ${ }^{3}$. We show why majorities at the constitution design stage tend to adopt at-large electoral rules in response to an increase in the size of the minority when the minority they are facing is relatively small. In this case, as the size of the minority increases, for the majority it becomes more effective to leverage on its sheer size instead of risking to concede representation to voters from minority-elected districts. However, as the minority becomes larger (closer to a fifty-fifty split), the possibility of losing the whole city induces the majority to prefer minority votes to be confined in minoritypacked districts. Single-member district electoral rules serve this purpose. This shift in the preferences of the (constitutional) majority, first towards an at-large

\footnotetext{
${ }^{3}$ See Cutler, Glaeser, and Vigdor (1999) for a detailed account of racial segregation patterns in the United States. The assumption of geographic clustering will be maintained throughout the paper.
} 
electoral rule, and then towards a single-district rule as the size of the minority increases, is precisely what the data show.

When discussing local politics in the US, one is immediately thrown into the area of race relations. ${ }^{4}$ In fact, it is quite compelling to identify the "majority" with the whites and the "minority" with racial "minorities" (perfect choice of words!). The evolution of voting rights, especially in the South, allows us to test implications of the model regarding the endogenous institutional choice. Until the mid-sixties, before the civil right movement and the Voting Rights Act of 1965, racial minorities (mainly blacks) in the South were essentially disenfranchised by a battery of regulations that, although color-blind on paper, were in practice directed to severely limit black vote. In this context the choice of electoral rules and forms of governments had not much to do with a white majorities' attempt at controlling black influence on city governments, since blacks did not vote. After the mid-sixties, due to novel federal Voting Rights legislation, black influence increased substantially in terms of their ability to elect representatives. Indeed, after the Voting Rights Act of 1965, we show that decisions about electoral rules reflected changes in the relative size of the white and black populations in a way consistent with our model.

Manipulation of electoral rules is not a prerogative exclusive of American cities. Alexander (2005, p.211) describes in detail the 1947 Gaullist manipulations of electoral rules in France. In the Paris area where the Gaullist alliance was weak they introduced proportional representation, in rural areas where the alliance was strong, they introduced plurality rule. Krenzer (2005, p.229) describes strategic manipulation in Germany. One could go on.

Our empirical results on (within-)US cities variation are quite consistent with previous findings on the cross-country evidence in Alesina, Aghion, and Trebbi (2004). In both cases constitutional choices do not seem to occur behind

\footnotetext{
${ }^{4}$ For discussion of the importance of race in American local politics, see for instance Hacker (1992), Huckfeld and Kohfeld (1989) and Wilson (1996) amongst many others. Alesina, Baqir, and Hoxby (2004) argue that even the design and number of local jurisdictions in the US depends upon race relations.
} 
a veil of ignorance in the sense that, as the minority increases its size and/or its political rights, the majority tries to make constitutional changes that limit the protection of minorities, while behind a veil of ignorance exactly the opposite should happen (as one would take into account the likelihood of belonging to a minority).

The paper is organized as follows. Section 2 illustrates the model. Section 3 describes the institutional context of US city government to which the model is applied and our data. Section 4 illustrates our empirical results. The last section concludes.

\section{The model}

The structure of the model is as follows. There are two groups of voters, whites $(W)$ and blacks $(B)$. We denote the initial relative size of group $B$ as $\pi>0$, so that the size of group $W$ is $(1-\pi)$. The whites are, initially at least, a majority (we restrict $\pi<1 / 2$ ) and they are those who choose the electoral rule for the city (in short, we call the choice of the electoral rule: "constitution"). This is because either the blacks are disenfranchised at the time of the constitutional choice or they were outvoted at the constitutional table. The white choose a constitution with an eye on maximizing their expected utility arising from a policy outcome which will be decided by an elected council. In order to make the problem interesting there is uncertainty in the relative share of the $W$ and $B$ voters, so that the constitutional writers cannot be sure ex ante of the composition of the council. In other words, there is a shock to the composition of the electorate between the writing of the constitution and the choice of the policy. Moreover, the composition of the council depends on the electoral rule chosen. This modeling strategy builds upon the incomplete social contracts ideas of Aghion and Bolton (2003). We now present the model more formally. 


\subsection{Agents and expected utility}

We first present a basic version of the model. We discuss extensions later. The population is equally spread over three electoral districts, numbered $1,2,3$, and with $M$ individuals in each. Each district chooses a seat in the council. The initial number of $B$ and $W$ voters in each district are given by $B_{i}$ and $W_{i}$ for $i=1,2,3$. We assume that:

$$
\begin{aligned}
& W_{1}=M ; \\
& W_{2}=W_{3}=\left(\frac{1}{2}+z\right) M,
\end{aligned}
$$

where $z$ is a real number between $-1 / 4$ and $1 / 2$. In other words, the parameter $z$ will allow us to make comparative statics on the initial number of $B$ voters in districts 2 and 3. Note that this range of variation for $z$ insures that $0<\pi<1 / 2$. Thus, $z$ parametrizes the size of the ex ante $W$ majority. Indeed, we have:

$$
\sum_{i} W_{i}=(2+2 z) M=3(1-\pi) M
$$

therefore:

$$
z=\frac{1-3 \pi}{2}
$$

Thus, initially the $W$ voters have a majority and they can choose the electoral rule (constitution). Given the electoral rule, a three-member council is elected. The council decides the policy. After the constitution is chosen, there is a shock to the composition of voters in the city, to which the electoral rule cannot be made contingent upon.

More formally, we suppose that during the interim phase an exogenously given mass $L_{N}$ of new $B$ voters joins the polity ${ }^{5}$, with $L_{N}=\alpha M$ where $\alpha$ is a random variable uniformly distributed between 0 and an upper bound $\bar{\alpha} \in(1,2)$. Moreover, we assume that the newcomers are not evenly distributed across the

\footnotetext{
${ }^{5}$ One could assume that mobility across cities is affected by the nature of charter rules, electoral systems, and the identity of the mayor, an issue which we do not tackle in the model. See Epple and Romer (1991) for a classic treatment of endogenous mobility in a political economy model. However, empirical evidence of Tiebout sorting is scant. See Strumpf and Oberholzer-Gee (2002). We discuss this effect in Section 4.
} 
three districts, but that instead one half of them joins district 2, whereas the remaining half goes to district 3 (thus, no new $B$ voter enters district 1 ).

Different compositions of the council imply different policies. We assume that with no $W$ representative and three $B$ representatives the implemented policy is most unfavorable to the $W$ group which obtains a low utility level $\underline{r}$. With one $W$ representative the $W$ group ends up with the status quo utility level $u_{0}$; with two or three representatives the $W$ group achieves its maximum utility level $\bar{r}$. (Think of $\underline{r}$ as being the result of the $B$ group's most favorable policy being implemented, and of $\bar{r}$ as being the outcome of the $W$ group's most favorable policy).

This last assumption is twofold. First, note that the $W$ group is advantaged: with two $W$ councilmen the $W$ bliss point obtains and with only one $W$ councilman the status quo obtains. This may capture either one of two empirical features, or both. One is some inherent advantage of $W$; another, more interestingly, may capture the functioning of a council in the presence of a $W$ mayor. For the moment we are ignoring the role of the mayor and the specifics of the form of government, but we will return to this below. Second, the assumption implies that the size of the $B$ majority matters for the policy outcome; a two-one $B$ majority implies a different policy from a three-zero $B$ majority ${ }^{6}$. In any event the specifics of the policy outcome formulation do not affect the qualitative nature of the results, as we discuss below.

The ex ante expected utility of a $W$ constitution writer is then equal to:

$$
U_{w}=\left(1-p_{0}-p_{1}\right) \bar{r}+p_{1} u_{0}+p_{0} \underline{r}
$$

where $p_{j}$ denotes the probability that $j$ council representatives belong to the $W$ - group at the interim stage. The choice of electoral rules (the constitution) chosen by the $W$ voters will determine the value of $p_{0}$ and $p_{1}$.

Summarizing, the timing of events is as follows:

1. Electoral rules are chosen by the $W$ group.

\footnotetext{
${ }^{6}$ See Alesina and Rosenthal (1995) for an extensive discussion of this assumption and a comparison with alternatives.
} 
2. The interim distribution of preferences is realized, which translates into a majority of the council.

3. Payoffs realize.

\subsection{Electoral rules and ex ante expected utilities}

With an eye to the case of American cities, we now study two alternative elec-

toral rules. The first one, referred to as representation "at-large" $(A L)$, allocates all seats to the party that wins more than fifty percent of the votes. The second rule, referred to as "single-member district rule" $(S D)$, requires that each candidate runs in a particular district and obtains a majority of votes within the district in order to be elected.

Given our above assumptions as to the group composition of the three districts, we immediately have that $p_{1}=0$ under the $A L$ rule, whereas $p_{0}=0$ under the $S D$ rule. We now compute the expected ex ante utilities of constitution writers in the $W$ - group, respectively under these two electoral rules.

\subsubsection{Expected utility under the at-large rule}

Under the $A L$ rule all council seats will go to the $B$ group if and only if:

$$
B_{1}+B_{2}+B_{3}+L_{N}>W_{1}+W_{2}+W_{3}
$$

Then, the ex ante expected utility of constitution writers in the $W$ - group can be simply expressed as

$$
U_{W}^{A L}=p_{0} \underline{r}+\left(1-p_{0}\right) \bar{r}=\bar{r}-p_{0} \Delta,
$$

where $\Delta=\bar{r}-\underline{r}$ is the constitution writers' loss from losing the majority, and

$$
p_{0}=\operatorname{Pr}\left(B_{1}+B_{2}+B_{3}+L_{N}>W_{1}+W_{2}+W_{3}\right)=\operatorname{Pr}(\alpha>1+4 z)
$$

is the probability of losing the majority. Substituting for $z$ as a function of $\pi$ using (1), we have:

$$
p_{0}=\max \left(1-\frac{3}{\bar{\alpha}}(1-2 \pi), 0\right)
$$


so that the ex ante expected loss of constitution writers in the $W$ - group under the $A L$ rule, is equal to:

$$
L_{W}^{A L}=p_{0} \Delta=\left(1-\frac{3}{\bar{\alpha}}(1-2 \pi)\right)^{+} \Delta,
$$

where we use the notation

$$
x^{+}=\max \{x, 0\} .
$$

\subsubsection{Ex ante expected utility under the single-member district rule}

Under the $S D$ rule council seats are allocated at the district level. The probability of the $B$ - group winning a majority of two seats is equal to the probability that districts 2 and 3 be won by the $B$ group. Given that the same fraction of new $B$ voters are allocated to these two districts, which already start with the same fraction of $B$ voters ex ante, and given that there is a fixed majority of $W$ voters in district 1 , we immediately get that the $B$ - group obtains a two-seat majority with probability:

$$
p_{1}=\operatorname{Pr}\left(B_{3}+\frac{1}{2} \alpha M>W_{3}\right)=p_{1}=\operatorname{Pr}(\alpha>4 z)
$$

or, after substituting for $z$ using (1):

$$
p_{1}=\left(1-\frac{2}{\bar{\alpha}}(1-3 \pi)^{+}\right)^{+} .
$$

We can then re-express the ex ante utility of constitution writers in the $W-$ group under the $S D$ rule, as:

$$
U_{W}^{S D}=p_{1} u_{0}+\left(1-p_{1}\right) \bar{r}=\bar{r}-p_{1} \delta
$$

where $\delta=\bar{r}-u_{0}$ is the constitution writers' loss from losing the majority, and therefore

$$
L_{W}^{S D}=p_{1} \delta=\left(1-\frac{1}{\bar{\alpha}(1-f)}(1-3 \pi)^{+}\right)^{+} \delta,
$$

is the expected loss of constitution writers in the $W$ - group under the $S D$ rule. 


\subsection{The size of minorities and the choice of electoral rule}

Ex ante at the constitutional stage, individuals in the $W$ - group will simply choose the electoral rule that minimizes the expected loss $L_{W}$. Our main theoretical prediction can be summarized intuitively as follows. If initially the $W$ group commands a very large majority of votes, the constitution writers do not fear they can lose the majority under either rule, thus they are indifferent between the two rules. As the relative size of the $B$-group increases, however, at some point it becomes preferable for constitution writers in the $W$-group to move to $A L$ in order to reduce the power of the $B$ - voters in districts 2 , 3 by confronting them with the whole pool of $W$ - voters, including those in district 1 . Doing so allows the $W$-group to preserve its majority as long as the fraction of $B$-individuals does not become too large. Finally, when the fraction of $B$-voters becomes sufficiently large that it becomes impossible to prevent their becoming the new majority, moving back to the $S D$ rule allows the $W$-group to limit their losses: indeed, as $\pi$ becomes sufficiently close to $1 / 2$, the risk of losing all three districts and of thereby incurring the large loss $\Delta$, makes the $W$-group prefer a $S D$ system which guarantees them at least 1 seat in the council -and thereby limits their loss to $\delta<<\Delta$-given that in this case $B$-voters are restricted to commanding districts 2 and 3 only. Not surprisingly, this latter motive from moving back from $A L$ to $S D$ disappears if the loss incurred by the minority is independent of the size of the majority, that is if $\Delta=\delta$.

More formally, we can state:

Proposition 1 (a) Both rules $A L$ and $S D$ involve no utility loss to $W$-group individuals when $\pi \in\left(0, \frac{1}{3}-\frac{\bar{\alpha}}{6}\right)$; (b) if $\frac{\Delta}{\delta}>\left(1-\frac{1}{\bar{\alpha}}\right)^{-1}$, then there exists a unique cut-off point $\widehat{\pi} \in\left(\frac{1}{3}-\frac{\bar{\alpha}}{6}, \frac{1}{3}\right)$ such that

$$
L_{W}^{A L}<L_{W}^{S D} \text { if } \pi \in\left(\frac{1}{3}-\frac{\bar{\alpha}}{6}, \widehat{\pi}\right)
$$

and

$$
L_{W}^{A L}>L_{W}^{S D} \text { if } \pi \in\left(\widehat{\pi}, \frac{1}{2}\right)
$$


(c) if $\Delta=\delta$, then for all $\pi \in\left(\frac{1}{3}-\frac{\bar{\alpha}}{6}, \frac{1}{2}\right)$ the AL rule dominates the $S D$ rule.

Proof. Part (a) is straightforward. Part (b) follows from the fact that: (i) we have

$$
L_{W}^{A L}=0<L_{W}^{S D} \text { if } \pi \in\left(\frac{1}{3}-\frac{\bar{\alpha}}{6}, \frac{1}{2}-\frac{\bar{\alpha}}{6}\right)
$$

(ii) for $\pi=\frac{1}{3}$, we have:

$$
L_{W}^{A L}=\left(1-\frac{1}{\bar{\alpha}}\right) \Delta>L_{W}^{S D}=\delta ;
$$

(iii) $L_{W}^{A L}$ and $L_{W}^{S D}$ are both linear increasing in $\pi$ for $\pi \in\left(\frac{1}{2}-\frac{\bar{\alpha}}{6}, \frac{1}{3}\right)$; hence the existence of a unique cut-off $\widehat{\pi} \in\left(\frac{1}{2}-\frac{\bar{\alpha}}{6}, \frac{1}{3}\right)$ with the desired properties. Finally, to establish part (c), let us reason by contradiction and suppose that for some $\pi$ between 0 and $\frac{1}{2}$, we have

$$
L_{W}^{S D}<L_{W}^{A L}
$$

or equivalently since here $\Delta=\delta$,

$$
\left(1-\frac{2}{\bar{\alpha}}(1-3 \pi)^{+}\right)^{+}<\left(1-\frac{3}{\bar{\alpha}}(1-2 \pi)\right)^{+} .
$$

First, this cannot be the case for $\pi \in\left(\frac{1}{3}, \frac{1}{2}\right)$ since in that case (4) becomes:

$$
1<\left(1-\frac{3}{\bar{\alpha}}(1-2 \pi)\right)^{+},
$$

which is impossible if $\pi<1 / 2$. Second, suppose that (4) holds for some $\pi<1 / 3$. It cannot be the case that both expressions are positive, otherwise we would have

$$
\left(1-\frac{2}{\bar{\alpha}}(1-3 \pi)\right)<\left(1-\frac{3}{\bar{\alpha}}(1-2 \pi)\right)
$$

or equivalently

$$
1-\frac{2}{\bar{\alpha}}<1-\frac{3}{\bar{\alpha}}
$$

which is impossible; and it cannot be the case that

$$
\left(1-\frac{2}{\bar{\alpha}}(1-3 \pi)\right)<0<\left(1-\frac{3}{\bar{\alpha}}(1-2 \pi)\right)
$$

as this would imply that

$$
\frac{1}{2}-\frac{\bar{\alpha}}{6}<\frac{1}{3}-\frac{\bar{\alpha}}{6}
$$

again an impossibility. This establishes the proposition.

This proposition can be generalized to the case of $N$ districts. We do so in the following extensions. 


\section{Extensions}

\subsection{The $\mathbf{N}$ district case}

Suppose the polity's population is equally spread over the electoral districts, now numbered $1, \ldots, N$, and with $M$ individuals in each. We maintain the assumption that the same two types of (ex ante) districts exist:

$$
\begin{aligned}
& W_{1}=M ; \\
& W_{2}=\left(\frac{1}{2}+z\right) M ;
\end{aligned}
$$

where again $W_{1}$ districts are "all- $W$ " while $W_{2}$ districts are an identical mix of $W$ and $B$. We also maintain the assumption that district design is exogenously given as we focus on the electoral rule for given district design. There are $N_{1}$ districts like $W_{1}$, therefore $N_{2}=N-N_{1}$. For $N_{2}<N_{1}$, it is clear that under $S D$ the $W$ group cannot be blocked, no matter how large the group $\alpha M$ of $B$ voters is. We exclude this instance and focus on the more interesting case where $N_{2}>N_{1}$.

Now consider the blocking probabilities under $A L$ and under $S D$ respectively. Blocking under $A L$ will occur whenever the ex post total number of $W$-voters, $N M(1-\pi)$, is larger than the ex post total number of $B$-voters, $\alpha M+N M \pi$. Thus, nothing fundamental changes from the three-districts case, and we now have:

$$
p_{0}=\left(1-\frac{N}{\bar{\alpha}}(1-2 \pi)\right)^{+} .
$$

Turning to the $S D$ rule, let us first assume that each district $j$ of the $N_{2}$ districts receives a fraction $\frac{1}{N_{2}}$ of new comers, all of them belonging to the $B-$ group. In this case the probability that the $B$-group wins a majority of seats on the council, is simply equal to the probability that the $B$-group acquire a majority of votes in any of the $W_{2}$ districts, namely

$$
p_{N_{2}}=\operatorname{Pr}\left(\frac{\alpha M}{N_{2}}+\left(\frac{1}{2}-z\right) M>\left(\frac{1}{2}+z\right) M\right)
$$

that is

$$
p_{N_{2}}=\operatorname{Pr}\left(\alpha>2 z N_{2}\right),
$$


where now

$$
z=\frac{1}{2}-\pi \frac{N}{N_{2}}
$$

We then obtain:

$$
p_{N_{2}}=\left(1-\frac{N_{2}}{\bar{\alpha}}\left(1-2 \pi \frac{N}{N_{2}}\right)^{+}\right)^{+} .
$$

Once again, the constitution writers will choose the electoral rule that involves the lowest ex ante expected loss, where

$$
L_{W}^{A L}=p_{0} \Delta=\left(1-\frac{N}{\bar{\alpha}}(1-2 \pi)\right)^{+} \Delta
$$

and

$$
L_{W}^{S D}=\left(1-\frac{N_{2}}{\bar{\alpha}}\left(1-2 \pi \frac{N}{N_{2}}\right)^{+}\right)^{+} \delta\left(N_{2}\right),
$$

where it is reasonable to assume that the loss $\delta\left(N_{2}\right)$ to the $W$-group if the $B$-group acquires majority of seats on the council, is non-decreasing in the number of seats $N_{2}$ the $B$-group holds in that case.

Assume

$$
\bar{\alpha}<N_{2} .
$$

Then for $\pi$ very close to zero, both $L_{W}^{A L}$ and $L_{W}^{S D}$ are equal to zero, so that constitution writers are indifferent between the two electoral rules. Next, note that for all $\pi<1 / 2$, we have

$$
\left(1-\frac{N}{\bar{\alpha}}(1-2 \pi)\right)<\left(1-\frac{N_{2}}{\bar{\alpha}}\left(1-2 \pi \frac{N}{N_{2}}\right)\right),
$$

so that as $\pi$ increases away from zero, $L_{W}^{S D}$ becomes positive before $L_{W}^{A L}$ does; this in turn implies that for intermediate values of $\pi$, constitution writers in the $W$-group will prefer the $A L$ rule to the $S D$ rule, as the former dilutes the $B$-votes among the whole $W$-population. Finally, as $\pi$ becomes arbitrarily close to $\frac{1}{2}$, the expected loss $L_{W}^{A L}$ under $A L$ converges to $\Delta$, whereas the expected loss $L_{W}^{S D}$ converges to $\left(1+\frac{N-N_{2}}{\alpha}\right) \delta\left(N_{2}\right)$. It then follows that the $W$-group will choose the $S D$ rule whenever $\left(1+\frac{N-N_{2}}{\alpha}\right) \delta\left(N_{2}\right)<\Delta$.

We thus obtain a straightforward generalization of Proposition 1 to the more general case where the number of districts $N$ is arbitrary. Note however that 
condition (5) becomes hard to satisfy when the number $N_{2}$ of $W_{2}$ districts becomes arbitrarily close to $N$.

\subsection{Uneven distribution of newcomers}

In order to gain intuition in this and the following subsections, let us return to the three-district model employed in Section 2.1. In our analysis so far we assumed that equal numbers of new $B$ - group voters would choose to locate in districts 2 and 3. However, our reasoning and result extend to the case where a fraction $f>1 / 2$ of new comers choose say district 2 whereas the remaining fraction $(1-f)$ chooses district 3 . This obviously does not affect the probability $p_{0}$ of the $B$ - group winning all seats under the $A L$ rule since that probability depends only upon the overall fraction of $B$ - individuals in the overall population. Thus, we still have:

$$
p_{0}=\left(1-\frac{3}{\bar{\alpha}}(1-2 \pi)\right)^{+},
$$

so that the ex ante expected loss from the $A L$ rule, is still equal to:

$$
L_{W}^{A L}=\left(1-\frac{3}{\bar{\alpha}}(1-2 \pi)\right)^{+} \Delta .
$$

However, the $B$ - group will only win a majority of seats on the council if it wins a majority of votes in districts 2 and 3 , which in turn requires that it win a majority of votes in district 3 , which, of the two districts, is the harder one to win. Therefore,

$$
p_{1}=\operatorname{Pr}\left(B_{3}+(1-f) \alpha M>W_{3}\right)=\operatorname{Pr}\left(\alpha>\frac{2 z}{1-f}\right) .
$$

This yields:

$$
p_{1}=\left(1-\frac{1}{\bar{\alpha}(1-f)}(1-3 \pi)^{+}\right)^{+}
$$

with a corresponding ex ante expected loss under $S D$ rule equal to:

$$
L_{W}^{S D}=\left(1-\frac{1}{\bar{\alpha}(1-f)}(1-3 \pi)^{+}\right)^{+} \delta .
$$

Assume

$$
\bar{\alpha}<\min \left\{3, \frac{1}{1-f}\right\}
$$


so that $p_{0}=p_{1}=0$ for $\pi$ sufficiently small.

Then, it is easy to show that Proposition 1 continues to holds in its entirety when

$$
1-f \geq \frac{1}{3}
$$

since in that case,

$$
1-\frac{3}{\bar{\alpha}}(1-2 \pi)<1-\frac{1}{\bar{\alpha}(1-f)}(1-3 \pi)
$$

which implies that, as $\pi$ increases from zero, $p_{1}$ becomes positive before $p_{0}$ does. On the other hand, one can easily show that when (6) is violated, then the $A L$ rule is always weakly dominated by the $S D$ rule when $\frac{\Delta}{\delta}$ is sufficiently large.

\subsection{Gerrymandering}

An important practical consideration is that the design of district may itself be endogenous. In particular, the constitution writing majority may be try to "gerrymander" the districts in order to minimize the number of representative elected by the minority. The possibility of unconstrained gerrymandering obviously makes the $S D$ rule preferable to a majority writing the constitution. As we will discuss below, empirically this is an important consideration for American cities. How advantageous for the white majority it is to choose gerrymandering with a $S D$ system versus an $A L$ system, depends also on the nature of residential segregation in the city ${ }^{7}$. This is of course a well know issue in the vast literature on gerrymandering. ${ }^{8}$

In the context of the above model, the constitution writers in the $W$ - group will simply choose to maximize $f$, that is, to pack as many new $B$-voters as possible in one district, say district 2 , in order to prevent them from ever acquiring a majority of votes in the council. In the absence of any constraints on gerrymandering (one such constraint for example would be that differentials

\footnotetext{
${ }^{7}$ Cole (1976) for instance emphasizes how at large elections, while in principle should favor minorities which are spread out within city boundaries, in fact do not.

${ }^{8}$ On gerrymandering, see in particular Cox and Katz (2002) and Friedman and Holden (2005).
} 
between the number of voters across the various districts cannot be larger than a given percentage), the constitution writers will simply choose $f$ equal to one, in which case $S D$ will always dominates $A L$. However, if various constraints on gerrymandering limits the maximum $f$ that can be achieved by constitution writers in the $W$-group, then as we just saw in the previous subsection the conclusions of Proposition 1 will again hold as long as $f<2 / 3$.

Finally, it is interesting to note that the possibility of gerrymandering could give rise to the same pattern with $A L$ dominating for intermediate values of $\pi$ and $S L$ dominating for high values of $\pi$, even when the loss incurred by the $W$-group is independent of the size of the $B$-majority, that is, even when $\Delta=\delta$. To see this, let us slightly modify our basic model by assuming that as in Proposition1 by assuming that constitution writers in the $W$-group suffer from having the $B$-group hold even one (minority) seat in the council. Then, as the size $\pi$ of the $B$-group increases from zero to $1 / 2$, the $W$-group will first choose the $A L$ rule in order to dilute the $B$-voters among all $W$-voters as in our previous analysis. But then, as $\pi$ increases further, the only way to prevent the $B$-group from winning a majority of seats is to move from $A L$ to $S D$ and at the same time "gerrymander", that is pack all $B$-voters in one district.

Already without gerrymandering, the $S D$ rule already allowed the $W$-group to "waste" $B$-votes by preventing them from contaminating district 1 . With gerrymandering the wasting (or packing) effect of $S D$ is only reinforced: $B$-voters cannot outnumber $W$-voters now in two districts instead of one in the absence of gerrymandering. But the logic and predictions are basically the same with and without gerrymandering.

\subsection{Uniform distributions of voters across districts}

Suppose the three districts are evenly affected by any ex ante variation in the size of the $B$ population, namely:

$$
W_{i}=\frac{1}{2}+z, \text { for } i=1,2,3,
$$


we have

$$
z=\frac{1}{2}-\pi,
$$

and that new comers are also evenly distributed across the three districts. Then the probabilities of the $B$-group winning under the $A L$ and $S D$ rules, are the same and equal to:

$$
p_{0}=\left(1-\frac{3}{\bar{\alpha}}(1-2 \pi)\right)^{+},
$$

and the ex ante expected loss of constitution writers under the two rules are also the same equal to

$$
L=p_{0} \Delta .
$$

This underlies the importance of the unevenness of the distribution of $B$ within the electoral area (the city) if we want to explain why local constitutions shift from one rule to another as the relative influence of $B$ - voters increases. In particular, the well known pattern of segregation in American cities makes this uniform distribution case not relevant.

Now, suppose that while ex ante $B$-voters are evenly distributed across the three districts, ex post new comers migrate only to districts 2 and 3 . In that case, the probability of the $B$-group winning under the $A L$ rule is still equal to $p_{0}$, whereas their probability of winning under the $S D$ rule is now given by

$$
p_{1}=\left(1-\frac{2}{\bar{\alpha}}(1-2 \pi)\right)^{+} .
$$

But then it is easy to see that constitution writers in the $W$ - group will never prefer the $S D$ rule for values of $\pi$ close to $\frac{1}{2}$ since

$$
L_{W}^{S D}\left(\pi=\frac{1}{2}\right)=p_{1} \delta=\delta<L_{W}^{A L}\left(\pi=\frac{1}{2}\right)=p_{0} \Delta=\Delta .
$$

Given that

$$
\left(1-\frac{3}{\bar{\alpha}}(1-2 \pi)\right)<\left(1-\frac{2}{\bar{\alpha}}(1-2 \pi)\right),
$$

for all $\pi$, as before as $\pi$ increases away from zero, the ex ante expected loss $L_{W}^{S D}$ will become positive before $L_{W}^{A L}$ does. Overall, as $\pi$ increases from 0 to $1 / 2$, constitution writers will first be indifferent between the two rules, then 
will prefer the $A L$ rule because it dilutes $B$-votes, then may prefer the $S D$ rule because it reduces losses, but then eventually will always reverse to the $A L$ rule. As we shall see in the empirical analysis, this last reversal to the $A L$ rule (which is the one departure from Proposition 1) is not observed in our cross-city data.

\subsection{Mayors and managers}

Another dimension that differentiates between American cities, is the degree of autonomy of the "executive". In a mayor-council system the executive is more autonomous from the council. Therefore, it is more difficult for the council to influence the executive process relative to the council manager system. One way of modelling this situation is to assume that the majority needed to block the mayor is larger than the one needed to block a manager. An additional variation involves the power of the mayors which is different in strong mayors versus weak mayor forms of governments, as discussed below.

Without a veil of ignorance, if the $W$ majority always knew that it would elect the mayor it would choose a more powerful mayor. But following the same logic of above, this would not be necessarily the case if the $W$ majority is slim and there are unforeseeable shocks to the composition of the electorate. In the empirical part we also briefly explore the choice between mayor council system and manager council systems.

\subsection{Mayors and councils}

Our analysis and main conclusions in Proposition 1, remain unaffected if we replace the timing described in Section 2.1 by one in which: (i) the constitution is chosen; (ii) the mayor is elected; (iii) shocks to the composition of the electorate occur; (iv) the council is elected; (v) the policy is chosen. With the

$W$-group having an ex ante majority they would choose the mayor. As we have discussed above, our choice of policy outcomes for given composition of the council can capture this institutional structure. Note that the latter implies a non-simultaneous election of the mayor and the council, a feature that 
characterizes a sizeable fraction of American cities ${ }^{9}$.

What changes from Section 2.1 is that now, whenever the $B$ - group obtains a majority of seats on the council, it is their preferred policy which prevails in equilibrium. This in turn implies that the loss incurred by the $W$-group becomes independent of the electoral rule. But then, under the assumptions of Proposition 1, with equal number of new $B$-voters in the two districts 2 and 3 , the $W$-group will always weakly prefer the $A L$ rule since it dilutes $B$-voters among the overall $W$-population whereas moving to the $S D$ rule does no longer limit losses to the $W$-group if they lose the majority. On the other hand, if gerrymandering allows the $W$-group to pack all new $B$-voters in one district, then the $S D$ rule will always dominate as it prevents the $B$-group from ever obtaining a majority of seats in the council.

\section{Institutional setting and data}

In our empirical investigation in the next sections, we shall focus on the main prediction of our model, namely that an increase in the size of the minority makes $A L$ preferable over $S D$ if initially the minority group (the $B$ voters) represents a sufficiently small fraction of the overall population, whereas the opposite is true if initially the minority group represents a sufficiently large fraction of the overall population. In other words, the preference of constitution writers for $A L$ over $S D$, increases and then decreases with the initial size of the minority group.

With the aim of testing a (reduced form) model of endogenous choice of checks and balances, Aghion, Alesina, and Trebbi (2004) employ data on a vast cross-section of countries, including democracies and non-democracies. American cities offer a potentially "cleaner" sample for testing the hypothesis of constitutional endogeneity consistently. First of all, American cities are much more similar to each other than a cross-section of countries ranging from advanced

\footnotetext{
${ }^{9}$ See Alesina and Rosenthal (1995) for a discussion of staggered elections or simultaneous elections at the national level.
} 
democracies to developing dictatorships. Moreover, US cities present enough time-series variation to allow us to account for time-unvarying unobserved heterogeneity in the data, arguably a potential source of bias in cross-sectional analysis. Second, the racial divide (mostly white/black historically, most recently Whites/Blacks/Asians/Hispanics) has been a prominent feature of the institutional debate and political choice in US cities ${ }^{10}$. Moreover, bloc-voting within racial lines has empirical foundation. Third, the evolution of minority "voting rights" and the Civil Rights movement in the sixties suggest a transformation of the nature of democratic institution in US cities. Before the Voting Rights Act of 1965, African Americans in the South were largely disenfranchised, consequently the choice of electoral rules was rather irrelevant from a race-relation point of view. From the mid-sixties onward white majorities had to cope with black voters; therefore they had an incentive to adopt electoral rules and forms of governments that minimized black influence. This episode allows us additional robustness checks of our model of endogenous evolution of electoral institutions. We begin with a brief review of the history of voting rights in the South.

\subsection{Legal and judicial interventions on voting in the United States}

There was no constitutional protection for voting and electoral participation in the United States before the Civil War. ${ }^{11}$ African American individuals in state of servitude were neither granted citizenship nor, consequently, voting rights. After the war, during the Reconstruction (1867-1877), the Congress provided such constitutional protection with the ratification of the 14th Amendment in 1868 (conferring citizenship to all persons born or naturalized in the United States) and the 15th Amendment in 1870 (providing that the right of vote

\footnotetext{
${ }^{10}$ US cities are not the only example of local politics influenced by race relations. For a discussion of electoral rules and racial politics in elections in India see Pande (2003).

${ }^{11}$ We refer to the United States Department of Justice, Civil Rights Division, Voting Section for further details and reference for this section.
} 
should not be denied or abridged on the basis of race, color, or previous status of servitude). The Enforcement Act (1870) and the Force Act (1871) ensured additional legislative detail, among other things introducing federal oversight over elections. Such measures effectively induced an enlargement of the electoral franchise to the black minority, both in the South and the rest of the country ${ }^{12}$. Around 1872 more than three hundred Southern black legislators were holding elected offices.

However, after the 1877 compromise, following the election of the republican Hayes, the demilitarization of the South and steadily up until 1910 with the "Redemption", Southern whites succeeded in reimposing pre-war political equilibria. The introduction of a series of legal procedures, color-blind on paper but anti-black in practice, such as poll taxes, literacy tests, "grandfather clauses", "understanding clauses", vouchers of "good character", and disqualification for crimes of "moral turpitude" achieved the substantial disenfranchisement of the black minorities in the South. In addition, white majorities extensively entertained the practice of "white primaries"13. By the early 1900's the number of

\footnotetext{
${ }^{12}$ All voters were white male according to the Naturalization Law of 1790 .

Only with the 19th Amendment to the Constitution, which became law in 1920, women obtained the right to vote in all elections. Constitutional amendment proposals for the extension of the electoral franchise to women had begun in 1878 and were proposed in every session of the Congress for the following 40 years. Some States already had laws enabling women to vote before 1920. Examples are Utah, Colorado, Idaho, and Wyoming, the first State in the Union allowing women to vote in 1890. The States of New York, Massachusetts, New Hampshire, and New Jersey allowed women to vote at the end of the 18th century, but between 1777 and 1807 they revoked those clauses.

Also Asian, Native American and Mexican individuals were not allowed to vote, not being recognized as U.S. citizens. In 1924 Native Americans were granted citizenship and in 1948 the last state laws denying vote were overturned. Asians were able to obtain full citizenship after the progressive overturning of the Chinese Exclusion Act of 1882 completed in 1952.

${ }^{13}$ See Myrdal (1944) for a detailed account. According to Woodward (2002, p.85) "the state-wide Democratic primary was adopted in South Carolina in 1896, Arkansas in 1897, Georgia in 1898, Florida and Tennessee in 1901, Alabama and Mississippi in 1902, Kentucky and Texas in 1903, Louisiana in 1906, Oklahoma in 1907, Virginia in 1913, and North Carolina in 1915." Primaries were not open to racial minorities and were effectively used to skim out
} 
Southern black legislators was back to zero: an early exemplification of the endogeneity of political institutions to sudden shifts in the electoral franchise (see Kousser, 1999). According to Woodward (2002) in Louisiana registered black voters were 1,342 in 1904, down from a peak of 130,334 in 1896. This coincided with the appearance of extensive Jim Crow legislation at the State level in the South. Until the mid-sixties the number of Southern black legislators remained close to zero. This coincided with a seemingly marginal role played by the Supreme Court in the active defense of the 15th Amendment. ${ }^{14}$

It was only form the mid 1960's that the Supreme Court started an active monitoring of electoral participation provisions and apportionment of state legislative districts. In Baker v. Carr, 369 US 186 (1962), the Court ruled against malapportionment. In a series of cases (Wesberry v. Sanders, 376 US 1 (1964), Reynolds v. Sims, 377 U.S. 533 (1964), Fortson v. Dorsey, 379 U.S. 433 (1965)) the Court ruled in the direction of re-equilibrating the weight of rural and urban votes, favoring urban minorities, that is blacks. At the same time the federal government started playing a much active role as well. President Lyndon Johnson ratified the 24th Amendment of the Constitution ${ }^{15}$ (1964) and signed into law both the Civil Rights Act in 1964 and the Voting Rights Act in 1965.

The goal of the Voting Rights Act of 1965 is to remove strong obstacles in voting registration procedures for racial minorities. Section 2 of the Voting Rights Act included a broad reassessment of the principles embedded in the 14th and 15th Amendments. It deemed illegal the use of poll taxes, literacy tests, and the requirement of fluency in English for voting eligibility. Section 5 introduced black voters, hence the appellation "white primaries".

${ }^{14}$ However, there were exceptions. In Guinn v. United States, 238 U.S. 347 (1915), the Court ruled against a Oklahoma "grandfather clauses" provision, in Smith v. Allwright, 321 U.S. 649 (1944), the Court ruled against Texas' "white primaries", and in Gomillon v. Lightfoot, 364 U.S. 339 (1960), the Supreme Court found unconstitutional the practice of gerrymandering in the city of Tuskugee (Alabama).

${ }^{15}$ The amendment outlawed the poll tax in federal elections. Virginia ratified the amendment in 1977, albeit the ratification process was completed on January 23, 1964 (by 38 States). The amendment was ratified by North Carolina in 1989. The amendment was rejected by the State of Mississippi (and not subsequently ratified) in 1962. 
strict requirements of pre-clearance (by the District Court for the District of Columbia or the U.S. Attorney General) of new voting procedures ${ }^{16}$. The bill authorized federal supervision of black voters' registration in Alabama, Georgia, Louisiana, Mississippi, North Carolina (in 34 counties), South Carolina, and Virginia (Woodward, 2002). In South Carolina v. Katzenbach, 383 U.S. 301 (1966), the Supreme Court upheld the Constitutionality of the Act. In Allen v. State Board of Elections, 393 U.S. 544 (1969) pre-clearance conditions were specified for a series of "tests or devices" of minority vote dilution, including explicitly changes to at-large elections from single district elections.

As a consequence of the Voting Rights Act, the number of registered minority voters as a fraction of voting age population doubled and in some cases tripled in Alabama, Georgia, Louisiana, Mississippi, and Virginia between 1965 and 1988 (Grofman, Handley and Niemi, 1992). Amy (2002) reports that "the number of black elected officials in the United States grew an average 16.7 percent a year between 1970 and 1977, from 1469 to 4311" (p.129). ${ }^{17}$.

In the light of continuing racial polarization in 1970, 1975, and 1982 the Congress introduced amendments to the Voting Rights Act extending Section 5 of 5,7 , and 25 years and addressing the removal of persistent obstacles to effective voting by the newly registered racial minorities (like gerrymandering, annexations, at-large elections, multi-member districts, and other "structural changes" to prevent blacks from voting through electoral dilution). The Supreme Court followed suit, for example in White v. Regester, 412 U.S. 755

\footnotetext{
${ }^{16}$ Section 5 precisely indicates which political organizations are covered by the act through identification of specific parameters. States fully covered under the 1975 renewal of the Voting Rights Act are Alabama, Alalska, Arizona, Georgia, Louisiana, Mississippi, South Carolina, Texas, and Virginia. California, Florida New York, North Carolina, and South Dakota are only partially covered in specific counties and Michigan and New Hampshire in specific townships. See Data Appendix for details.

${ }^{17}$ In 1999 according to the Joint Center for Political and Economic Studies the total number of black elected officials was 5938 in the South (respectively 8936 in all U.S.), of which 340 were city mayors (resp. 450 nationwide), 2677 members of municipal governing bodies (resp. 3498 nationwide). There were no black senators in 1999 and 19 representatives form the South (39 black representatives nationwide).
} 
(1973) and, with respect to dilution associated with at-large elections, in Thornburg v. Gingles, 478 U.S. 30 (1986). During the 1980's and 1990's the federal government and the Supreme Court tended to diverge more frequently with respect to affirmative intervention in promoting minorities' political enfranchisement (particularly, with respect to affirmative gerrymandering). ${ }^{18}$

From this brief historical excursus, we need to remember two points germane to our empirical analysis:

1) Until the mid-sixties white majorities did not have to worry about black vote in the South; only with the Voting Act of 1965 blacks were really a political block vote to reckon with.

2) The implementation by the Courts of the Voting Rights Act also took up the issues of the choice of electoral rules, precisely to avoid choices (like at large elections) that would have favored the white majority. Thus, any attempt of the white majority to engage in the kind of strategic choices implied by our theoretical model would have to face potential challenges from the Courts.

\subsection{Data and summary statistics}

This section briefly reviews the main variables employed in the empirical analysis. We refer the reader to the Data Appendix ${ }^{19}$ for details on variables definition, data construction and sources. We used two sets of data; one includes

\footnotetext{
${ }^{18}$ In 1980 the Supreme Court imposed the requirement of proof of "racial discriminatory purpose" in vote dilution cases (Mobile v. Bolden, 446 U.S. 55, 1980). This was rectified by a 1982 Congress Amendment, dispensing from such proof. The Supreme Court substantially challenged "affirmative gerrymandering" in Shaw v. Reno, 509 U.S. 630 (1993) and Holden v. Hall, 512 U.S. 874 (1994) among the others. Under President Bill Clinton the National Voter Registration Act (also known popularly as the Motor Voter Act of 1993) aimed at strongly promoting voter registration (for example, through the department of motor vehicles structures, unemployment, and welfare bureaus). More recently the Help America Vote Act of 2001 has shifted back to individual States most of the supervisory power over the quality of electoral franchise. Voting Rights Acts renewal hearings are due in 2007.

${ }^{19}$ Due to space limitations we produce the Data Appendix in a separate document, available on request. Please refer to the authors' webpages for a downloadable version of the Data Appendix.
} 
characteristics of city governments and their institutional details; the other includes demographic, economic, and geographic characteristics of US cities. We collected information on US municipal governments characteristics for the period 1930-2000, at decade intervals, from the Form of Government Survey and Municipal Year Book by the International City/County Management Association (ICMA) in Washington D.C. ICMA is a professional organization of city managers and administrators publishing local government data since 1914 and a well-recognized scholarly source. ICMA survey data have been employed in a number of papers, including Baqir (2001), Sass and Pittman (2000), DeSantis and Renner (1992) among the others. Data from 1980 onward are available in electronic format; data before 1980 needed to be collected and entered from hard copies. For this reason we decided to collect data before 1960 only for the South, since it is in the South where the effect of the Voting Rights Act is more relevant and should show larger differences before and after the mid sixties.

From the various issues of the ICMA surveys we collected information on electoral rules and forms of government for each municipality, including: council size; number of district-awarded council seats; city form of government; number of councilmen belonging to different racial groups currently sitting in the council; mayor's veto power over council resolutions; mayor's vote restrictions in council resolutions; mayor's length of term in office; indicators of the presence of referendum, initiative or recall. We then constructed two "single district" variables: (i) $S D$, a dichotomous variable equal to 1 if all councilmen are elected at large, 0 otherwise; (ii) $y$, continuously defined as the fraction of councilmen elected in single districts. We also constructed two "form of government" indexes increasing in the power of the executive. The first index, indicated as FOG, takes the value of 1 for mayor-council, 0 for council-manager and -1 for Commission or Representative Town Meeting or Town Meeting. The second index, indicated as $S I N D$, is constructed as increasing function of provisions strengthening the executive (like mayor-council and veto power) and decreasing in provisions weakening the executive (for example, recall). ${ }^{20}$ With regard to

${ }^{20}$ The mayor-council form of government consists of an at-large elected mayor (the executive 
electoral rules in 2001 about 65.9 percent of the cities in the sample presented only at-large-elected councilmen, about 14.8 percent presented only districtelected councilmen. The remaining cities presented some combination of the two types of rules, with councils consisting of a fraction of councilmen representing specific geographic areas and the others "representing the whole city".

From the decadal issues of the Bureau of the Census' of Population we collected information on total population, racial groups sizes, median income, and geographic characteristics of Places and Minor Civil Divisions (MCD's) ${ }^{21}$. From 1930 to 1970, the data available allow for a breakdown into three groups: white, black, and other races (we did not distinguish between foreign-born or native). From 1980 the Census allows for a more refined breakdown (in general the breakdown includes at least Whites, Blacks, Hispanics, Asians, Pacific Islanders, and Native Americans ${ }^{22}$ ). Since our empirical analysis runs from the thirties to the nineties, for consistency we used the three group break down (White, Blacks, others) for the entire sample. Our variable of interest was the size of non-whites (we also reproduced all our result using blacks instead of non whites, with virtually no changes in the results). ICMA and Census data were subsequently merged on the basis of geographic identifiers and FIPS codes (unique identifiers) whenever available or matched by city name and individually checked. Details on the procedure are available in the Data Appendix.

A final caveat. ICMA surveys present different coverage depending on the year. We review their representativeness in terms of population characteristics vis-a-vis the corresponding entire Census population of places and MCD's in Appendix A. The bottom line is that sample of US cities collected by ICMA

branch) and a legislative branch, the council of councilmen (or aldermen), elected by ward, at-large, or a mix of both rules. The mayor acts as chief executive officer of the city. Mayor's powers vis-a-vis the council vary within this typology of government. Typically we have two variants, weak-mayor and strong-mayor..The council-manager form of government consists of a legislative branch, the council, which selects and supervises a professional administrator, the city manager. The manager is in charge of the implementation of the policy and day-to-day municipal administration and can be removed or fired by the council at will.

${ }^{21}$ Definitions and references in the Data Appendix.

${ }^{22}$ See Data Appendix. 
is representative of the total population of relatively large cities, above 2,500 inhabitants, and less representative of the full population of the Bureau of the Census Places and Minor Civil Divisions (MCD's). This is the reason why in what follows, we always report results for the entire available sample and for a subsample of cities above this threshold of 2,500; the results are in general almost identical. We were also able to obtain the full lists of cities sampled from ICMA for the last survey in year 2001 and we verified the absence any response selection in the survey ${ }^{23}$. In the Data Appendix we report summary statistics for the key variables of interest for the sample of all US cities and for the sample of Southern cities. We now proceed to an empirical test of our model.

\section{Empirical results}

\subsection{The choice of electoral rules}

Empirical Strategy - Our main theoretical prediction is that the preference of constitution writers for at-large over single-district increases and then decreases with the initial size of the minority group.

We report a test of this hypothesis in Table 1 . The empirical strategy that we employ in this table and in the majority of the following ones is to stick to a simple, yet flexible, linear (in the coefficients) parametric two-way panel model in which we account for unobserved, time-invariant heterogeneity at the city level and for time-specific effects. Proposition 1 hypothesizes a non-monotonic, $U$-shaped relationship between either $S D$ or $y$ and $\pi$, which provides intuitive appeal to the choice of fitting a quadratic relationship between $S D$ or $y$ and $\pi^{24}$. For each city $i$ in year $t$ let us define the political variable of interest $y_{i t}$ (the fraction of councilmen elected by ward or district), the fraction of the

\footnotetext{
${ }^{23}$ See Appendix C.

${ }^{24}$ Further, simple non-parametric evidence is provided in what follows. A third-order polynomial produced a very similar fit as the quadratic model we report. The main difference recurred for high levels of $\pi$, where the race of the charter writers could be non-white. Higherorder polinomials produced a worse fit than the quadratic.
} 
minorities ${ }^{25}, \pi_{i t}$, a matrix of $(k \times 1)$ controls $X_{i t}$ and the two-way error as $u_{i t}=\alpha_{i}+\delta_{t}+\eta_{i t}$. We specify ${ }^{26}$ the following:

$$
\begin{aligned}
y_{i t} & =\beta_{0}+\pi_{i t} \beta_{1}+\left(\pi_{i t}\right)^{2} \beta_{2}+X_{i t}^{\prime} \gamma+\alpha_{i}+\delta_{t}+\eta_{i t} \\
\text { for } i & =1, \ldots, N \text { and } t=1, \ldots, T .
\end{aligned}
$$

Controlling for city-specific unobserved characteristics is relevant to our empirical strategy. Historical, geographical, and cultural conditions explain much of the variation in political institutions at the city cross-sectional level (about 67 percent). However, such conditions are often difficult to measure directly and would bias, if omitted, any inference concerning the role of changes of racial composition of the city in the choice of electoral rules. Employing within-city variation allows us to account for such unobserved heterogeneity and estimate consistently the vector $\left(\beta_{1}, \beta_{2}\right)$. Time-specific effects are similarly useful in accounting for across-the-board effects, such as federal legislation, that again need to be controlled for, especially in the post-1965 period $^{27}$ when indeed legislation was extremely active. We address the issue of serial correlation in the error component $\eta$ by relaxing the assumption of independence and clustering at the city level. Conditional heteroskedasticity of unknown type is also accounted for.

Identification of (7) is also particularly relevant. The most likely source of reverse causation affecting (7) is endogenous sorting across municipalities driven by more favorable electoral rules. Minority voters may move towards cities with better chances of representation or white voters may move out of cities with excess minority representation. Hence, Tiebout sorting would predict a correlation between changes in city racial composition and in electoral rules of the opposite sign to what predicted by our model. Specifically, suppose that

\footnotetext{
${ }^{25}$ Notice that the theoretical restriction $\pi<0.5$ is satisfied in the data, as more than 90 percent of cities are below $\pi=0.361$ for the whole sample of American cities and below $\pi=0.433$ for the South.

${ }^{26}$ The same specification is also employed for $S D$. However in that case we assume a logistic distribution of $\eta$.

${ }^{27}$ Formal F-tests for this specification support the use of a two-way setup. Both groups of fixed effects are jointly significant in every specification.
} 
a city changes its electoral rule in favor of white voters against black voters, then the percentage of the latter should go down because of Tiebout sorting (and possibly the white group should increase in number reducing the fraction of blacks even further). Instead, we show below that, as the share of blacks increases, electoral rules turn against them. In this light the estimates presented below need to be interpreted as lower bounds of the effects the theory predicts.

A final issue on the empirical strategy concerns the timing of the Voting Rights Act. Table 1 is divided in two parts: for the period before and after the Voting Rights Act of $1965 .^{28}$ The first year for which complete survey data from ICMA are available after 1965 on electoral rules (and forms of government) is 1967, which we take as the dividing line for pre- and post-Voting Rights Act and we match to the 1970 Census data. The non-monotonic relation should emerge only in case of an enfranchised minority. From the time of its introduction, the Voting Rights Act represented a sudden extension of the political franchise to blacks. We employ such date as an informative source of variation for institutional manipulation, particularly in Southern cities.

Results - The first four columns of Table 1 refer to the sample of Southern cities $^{29}$. Column (1) shows the basic specification including all cities. Column (2) focuses on cities above the 2,500 threshold (remember the ICMA sample is more representative for cities above this size) columns (3)-(4) include additional controls for city size, median income, and a deterministic time trend at the State level. The last two columns show the same regressions for the sample of all US cities.

The model calls for a negative linear and a positive quadratic term on the

\footnotetext{
${ }^{28}$ Note that one may want to exclude cities in which whites are a minority. There are very few of those and in addition even when whites are a minority in terms of number of inhabitants, demographic factors and vote participation patterns may still make them a majority as active voters (see Amy 1993, p.125 for an example). For this reason it is unclear which cities to drop from the sample. We tried a few experiments and our results appear robust.

${ }^{29}$ As for all the rest of our empirical analysis we exclude from the sample those cities for which we have information that the change of structure of government is the result of court mandate or State Law. ICMA data provide partial information with this respect.
} 
share of the non-white minority; as this share increases, at-large elections become more desirable up to a point in which the voting minority is so large that the majority is better off by "packing" minority votes through single-district elections. The signs of the coefficients are consistent with this story. Looking for instance at column (1) the estimated coefficients imply that this $U$ - shaped curve reaches a minimum at about 29.2 percent $(0.292=0.885 / 3.028)$ non-white minority. (Note that 66.7 percent of the sampled cities in year 2000 were below this level). The last two columns show that when we look at the US as a whole, the sign of the coefficients is the same as that for the South, but the size of the coefficient is smaller in absolute value, roughly half, suggesting that these racial effects are stronger in the South. To gauge quantitatively the size of the two effects, one can start observing the empirical distribution of the size of minorities in Southern cities. Consider as a benchmark the cross-sectional distribution of minority sizes in year 2000 (but likewise for all the decades 1970-1990) for those cities employed in the column (1) sample. The first quartile (Q1) for the fraction of minority is 9.76 percent and the third quartile (Q3) is 34.86. At Q1, given estimated coefficients in column (1) of -0.885 and 1.514 (with clustered standard errors respectively 0.308 and 0.475 ), an increase of one standard deviation of minority sizes (16 percent) implies a reduction of -5.56 percentage points $\left(-0.0556=-0.885^{*} 0.16+1.514^{*}\left(0.2576^{\wedge} 2-0.0976^{\wedge} 2\right)\right)$ of the fraction of single-district seats. This is equivalent to about one seat switching from singledistrict to at-large in a council of 18 seats. At Q3, the same increase of one standard deviation would instead produce an increase of about +6.6 percentage points in the fraction of single-district seats. This would be equivalent to about one seat switching from at-large to single-district in a council of 15 seats. These two estimates appear quantitatively reasonable. In order to evaluate the size of these effects one has to remember that the Voting Rights Act itself imposed limits on how much cities could switch to $A L$ systems! $!^{30}$ In other words, without Supreme Court involvement, these effects would have been surely larger, even if possibly not as large as the disenfranchisement of the 1877-1900.

${ }^{30}$ See below for further details. 
The bottom panel shows regression for the Sample of Southern cities before the Voting Rights Act, for the period 1930-1970 ${ }^{31}$. Here the coefficients on the size of the minority and its square are statistically zero. This is consistent with our hypothesis that before the Voting Act electoral rules were unaffected by the city racial composition, since racial minorities (blacks) were almost completely disenfranchised.

Table 2 presents estimates employing a discrete dependent variable, $S D$, and a conditional logistic estimator grouping observations at the city level. This is corresponds to what part of the applied literature calls fixed effects (or conditional) logit model. The implications of Table 1 carry over to this specification check consistently with the predictions of Proposition 1. Given that the likelihood contributions of cities which do not change their electoral rule are zero, one observes a smaller number of observations than in Table 1. For what follows we prefer to limit ourselves to the analysis of the continuous variable $y$ given the greater flexibility allowed by the continuity of the dependent variable.

Time persistence is an important characteristic of political systems, therefore we employ a standard dynamic panel technique, through first differencing and application of the Arellano and Bond (1991) GMM estimator, in Table 3. This procedure has the double advantage of enriching our basic specification of a dynamic component and addressing the issue of endogeneity of size of the minority through the use of lags of the exogenous variables (the time fixed effects), endogenous variables (city population and fraction of the minority), and the dependent variable. The specification we employ is:

$$
y_{i t}=y_{i t-1} \theta+\beta_{0}+\pi_{i t} \beta_{1}+\left(\pi_{i t}\right)^{2} \beta_{2}+X_{i t}^{\prime} \gamma+\alpha_{i}+\delta_{t}+\eta_{i t}
$$

Together with a significant autoregressive component $(\theta$ around 0.3 in column (1), panel a) the first three columns show the same patterns of coefficients on

\footnotetext{
${ }^{31}$ The panel observation we indicate as 1970 indeed employs information on 1967 ICMA data, matched with 1970 Census demographic variables. We also repeated all the analysis matching the Census with the 1972 ICMA data with very similar results. We opted for 1967 because of better coverage and vicinity to 1965, the actual date of enactment of the bill.
} 
the share of minority variable as Table 1 . The minimum in this $U$ curve is reached at a fraction of the minority of about 33.8 percent. The coefficients $\beta_{1}$ and $\beta_{2}$ for the size of the minority are in the same order of magnitude of our previous results in Table 1 , but about two times larger $\left(\beta_{1}=-1.644\right.$ and $\beta_{2}=2.645$ in column (1) with one-step robust standard error respectively 0.712 and 1.002). Quantitatively a stronger result, this would imply a change of 1 seat from single-district to at-large in a council of 9 at Q1 (about -11.27 percentage points) and a change of 1 seat from at-large to single-district in a council of 10 at Q3 (about +9.97 percentage points). Again we also find no significant role for racial composition in the pre-Voting Rights South (panel b). Finally, we need to note that due to the lag requirements of the model we find ourselves confined to a smaller sample (especially for the all US sample: it does not go further back than 1980, so we can employ at most one lagged difference).

The specification checks for the dynamic model are reported at the bottom of each panel of Table 3. For Columns (1) and (2) the second order serial correlation p-values of the one-step procedure does not to rise concerns over the validity of the instrument set, but the overidentification test's p-value obtained from the GMM two-step procedure seems low (although not granting rejection at any confidence level for the South and not at 5 percent for all US) given the low-power properties of such tests. However, additional robustness checks and the consistency of the standard linear model and this simple dynamic extension are source of reassurance.

\subsection{Additional nonparametric evidence on the choice of rules}

Simple nonparametric evidence supports the main prediction of the model as well. We expect to observe two basic regularities concerning the within variation in the data. First, the slope of a within regression of the single-district variable on the fraction of the minority (or the fraction of blacks) should be increasing in subsamples where the average minority size is increasingly higher. Second, 
we would expect statistically significant coefficients of negative sign to appear at relatively small values of the fraction of the minority (where the downwardbending part of the $U$-shaped parabola is steeper) and statistically significant coefficients of positive sign to appear at relatively large values of the fraction of the minority (where the upward-bending part of the $U$-shaped parabola is steeper). A flat and insignificant relationship should appear in the middle range. We borrow a simple modification of locally weighted scatterplot smoothing (lowess) from Imbs and Wacziarg (2003) and run a series of within-city regressions in the relevant interval of minority sizes $\pi \in[0.05,0.55]$ employing a symmetric bandwidth of half a cross-sectional standard deviation of minority size $(17 / 2=8.5$ percent $)$. Again we focus on the South of the United States for the period post- and pre-1967. Specifically for each subsample we estimate:

$$
y_{i t}=\beta_{0}+\pi_{i t} \beta_{1}+\alpha_{i}+\delta_{t}+\eta_{i t}
$$

At increments of $1 / 5$ of a percentage point of minority fraction (i.e. 0.002) we register the within-city slope $\left(\beta_{1}\right)$ and its t-statistic. We then regress the estimated slopes and the t-statistics against the corresponding mid-sample fraction of the minority. In both regressions a positive coefficient on the mid-sample fraction of the minority would confirm each of the two hypotheses discussed above. Table 4 reports results for both post- and pre-1967 for nonwhite minorities and confirms our predictions.

As expected, coefficients move from being prevalently negative at low levels of $\pi^{32}$ to being prevalently positive at higher levels of $\pi$ (around $1 / 2$ ). Over the interval $^{33} \pi \in[0.05,0.22]$ the average coefficient for nonwhites in the post-1967 South is equal to -0.601 and gives an estimate that is larger but comparable to the effect of the parametric estimate at Q1 (for an increase of 17 percent the change in single-district is -0.102 versus -0.0556 of the F.E. parametric model

\footnotetext{
${ }^{32}$ Notice that flats at low values of $\pi$ are justified by the relative equivalence of at-large and single-district rules in cases where minorities would not gain representation under any of the two rules.

${ }^{33}$ Bounds for the intervals of $\pi$ are chosen to divide in three equal parts the support for the downward, flat, and upward part of the curve.
} 
and -0.1127 of the dynamic panel); the same holds for the average coefficient in the interval $\pi \in[0.38,0.55]\left(\beta_{1}=0.857\right)$ comparable to the parametric effect at Q3 (0.145 versus 0.0660 in the F.E. model and 0.0997 in the dynamic panel). A within regression in such small subsamples (due to the small bandwidth) is demanding but nonetheless the main nonlinearity is detectable. However, we detect large fluctuations in the coefficients due to the varying (and small) number of changes in electoral rules in each subsample. We observe relatively larger (in absolute value) t-statistics mostly around the extrema of the interval of minority sizes (negative at low levels of $\pi$ and positive at large levels of $\pi$ ) and generally insignificant results otherwise.

\subsection{Electoral rules and minority representation}

Our basic story holds that electoral rules affect the ratio of minorities elected differently. This is the reason why the constitution writers choose differently in the first place. The ratio of non-white council members should display dependence on the electoral rules in order for the fundamental tenet of our analysis to be verified. Moreover, different rules should have different effects on minority representation at different minority sizes. By quantitatively estimating the impact of electoral rules on minority representation, we provide evidence that both statements are verified by the data and that the estimated effects move in the direction our model presumes and rationalizes.

The representational ratio is the fraction of minority councilmen in a council divided by the fraction of the population that belongs to the minority and is available for our all-US cities sample in year 1980, 1990, and 2000. ${ }^{34}$ A large section of empirical Political Scientists have employed the representational ratio as the typical measures of the degree of "proportionality" of an electoral system (i.e. if composition of population racial group maps one-to-one into the racial

\footnotetext{
${ }^{34}$ Very few cities for the all US sample present representational ratios of minorities of more than 1, indicating over-proportional representation. Even less of them are present in the South. In order to limit the role of these outliers we limit the representational ratio to be less than 5 .
} 
composition of the legislative body). We regress it on our variable of interests, the single-district rule variable. Table 5 reports the results. The null hypothesis that the electoral rule adopted by a city has no association with the representational ratio is soundly rejected in both a pooled cross-sectional regressions (Panel a) and in fixed-effect regressions in which time invariant city-specific unobserved heterogeneity is accounted for (Panel b). All specifications include year fixed effects and a set of standard controls for city size (log population) and income levels (log household median income in 1990 dollars) and we apply the same clustering as Table 1. Looking at columns (1) and (2) for the South and (3) for the whole country, single-district rules substantially increase the chance of minorities to be proportionally represented at the municipal level. Recalling that the fraction of single-district seats, $y$, is defined over the $[0,1]$ interval, our results in column (1) imply an average increase of the representational ratio of the city council between 13 (in panel a) and 35.4 (in panel b) percentage points from switching from a fully at-large rule to a fully single-district rule ${ }^{35}$. This is a quantitatively substantial effect: each black or minority vote has something less than $1 / 3$ more weight in terms of electoral representation under single-district than under at-large elections. Both our cross-sectional and fixed-effect analysis provide quantitatively similar evidence and, as one would expect, such results are quantitatively stronger in the more segregated South.

In columns (4)-(7) we provide evidence that the impact of the single-district rule on the representational ratio is actually non-monotonic in the size of the minority by including an interaction of the single-district variable and the fraction of non-whites (the level of non-whites is included as well). At low levels of minority size both at-large and single-district should be indistinguishable in warranting representation: minority are just too small to achieve representation under any rule. However, as the minority size increases single-district will offer better chances of representation to geographically segregated minorities vis-a-

\footnotetext{
${ }^{35}$ Virtually identical results are obtained when we define the left hand side as fraction of non white concilpersons over the fraction of non white population. We use specifically the black group in order to make our results more comparable with the previous literature.
} 
vis at-large. Such effect will diminish, however, when the minority becomes so large that some district votes (those beyond simple majority in the district) will be wasted. This implies that the sign of the coefficient should be negative on the interaction term. In panel a) columns (4)-(7) present interactions with the predicted sign that are significant at standard confidence levels and reject the absence of a non-monotonicity. Moreover, single-district maintains his expected positive effect, while the fraction of minority has a positive coefficient. The picture in the fixed effect analysis in panel b) is less clear, primarily because the required variation in the data is a contemporaneous change over three dimensions: electoral rules, fraction of minorities, and number of minority councilmen. Albeit our data set is rich, this requirement is probably too stringent.

We are not the first to observe that at-large election favors the white majority and our results are consistent with a substantial body of Political Science literature on the matter. For instance Amy (2002) writes that "the system of voting in at large elections often makes it virtually impossible for minority candidates to get elected. At-large elections require candidates to get a majority or plurality of the vote to win, which usually allows a white majority to take all seats and to deny minorities any representation at all." (p. 150) ${ }^{36}$. Sass and Pittman (2000) also provide panel data evidence on the effect of electoral rule on minority representation reporting a representational ratio differential of 36 percent, quite comparable with our linear estimates. Our results extend to more recent data and a substantially larger sample of cities. We are not aware of previous empirical study pointing at the non-monotonicity in the effect of single-district rules on minority representation.

\subsection{The Voting Rights Act and electoral rules}

This section investigate further how the Voting Rights Act imposes a constraint on the constitutional choice of the white majorities. The Voting Rights Act not

\footnotetext{
${ }^{36}$ For similar views see Berry and Dye (1987). For empirical cross-sectional analysis see Karning and Welch (1982), also cited in Amy (2002).
} 
only removes (and has removed) obstacles to minority voting registration. Any jurisdiction covered under Section 5 of the Voting Rights Act has the duty of obtaining pre-clearance for any change concerning voting from the office of the Attorney General through the Department of Justice or United States District Court for the District of Columbia. Every change proposed is individually reviewed from the Department of Justice and cleared ${ }^{37}$ "if the change does not lead to a retrogression in the position of minority voters with respect to the effective exercise of the electoral franchise". Case by case clearance is based on the study of the most recent Census and electoral data available and through interviews to concerned parties.

The implementation (both by Law and through the Courts) of the Voting Rights Act has been extremely successful, but it is hard to presume it has been perfect and definitive. The very fact that the VRA has been repeatedly renewed over time indicates that pressures towards distortion of voting institutions are still present and perceivable (the VRA is due for renewal in 2007). Riker (1984) brilliant account of a camouflaged litigation in a council-manager redistricting dispute (albeit in a different legal context) shows an example of how political institutions may still be distorted in favor of an incumbent majority even in such situations. We believe our analysis detects such pressure in the form of systematic strategic changes in electoral rules under the current legal constraint. The estimated dimension of the changes detected seems not so large to lead to a severe under-representation of blacks. Severe under-representation would raise legal highbrows and court challenges and, ultimately, legally-imposed changes in the electoral rule (which we exclude from our analysis).

There is also some evidence that the Voting Rights Legislation is progressively more effective in detecting strategic electoral manipulation. Table 6 reports median values for ethnic fragmentation, fraction of blacks and fraction of non-white minority. For the seventies both for the set of fully- and partiallycovered States in the South, median minority sizes of cities increased in the vari-

\footnotetext{
${ }^{37}$ Information concerning objected changes can be found in the motivation letters available at http://www.usdoj.gov/crt/voting/sec_5/obj_activ.htm.
} 
able of single-district rule are substantially higher and well outside confidence intervals of medians of cities decreasing single-district, in a direction consistent with a degree of manipulation. However, in the eighties the difference in the medians is reduced and gets substantially smaller in the nineties.

Finally, the coverage on the Voting Act is endogenous: the loci of greater potential conflict are those to which the VRA applies in full coverage. They are also the ones where the effects we detect are clearer. Table 7 reproduces the post- Voting Rights result of Tables 1 and 3 for those cities belonging to fully VRA-covered States and shows, especially for the basic panel model, greater significance and quantitatively larger coefficients. In column (2), panel a), the linear coefficient increases of about 48 percent, the quadratic 18 percent vis-a-vis the benchmark reported in column (1).

\subsection{Form of government}

For given council composition, there is anecdotal evidence that the form of government may play a role as well in the enfranchisement of minorities. The two main forms, mayor-council and council-manager, differ with respect to the role of the mayor as the pivot of the executive (stronger in the first instance). Our model is not centered on the role of form of government ${ }^{38}$ but in this section we briefly review empirical evidence which may be per se relevant. In cities where the white voters hold a solid majority and are almost sure of electing a white mayor, they may have prefer a strong mayor form of government. On the other hand, in cities with a closer fifty-fifty split, the white constitutional writers may prefer a council-manager form of government to avoid the risk of ending with a black strong mayor. The following quote from an editorial from a newspaper targeted to Hispanics in San Diego (La Prensa, April 24, 2004) is an example of how form of government may enter the picture. In discussing proposed changes in the charter of the city of San Diego, the editorial concludes that " For Hispanics having a strong mayor form of government does not bode.... well for this

\footnotetext{
${ }^{38}$ See our discussion in the extensions of the basic model.
} 
community. Putting so much power into one person's hands...translates into control by Republican right wings. Regardless of the changing demographics, i.e. the continual growth of the Hispanic, Asian, Filipino, black community political representation in the city of San Diego will be held by a diminishing number of white ...citizens." A relatively weak council hardly exercises any effective check on executive powers. A powerful council plays exactly the opposite role in council-manager structures.

We start considering two indexes of form of government, FOG and SIND, increasing in the degree of executive power. A strong mayor could be preferred by the charter writers as long as their position as majority of the city is strong, but a strong mayor is relatively riskier whenever minorities are large enough. At that point the more collegial council-manager form could be employed (given that whites could still be able to seat in the council). Therefore, to be congruent with our results on electoral rule, we would expect a positive coefficient on the size of the minority and perhaps a negative quadratic term in a regression where form of government is the dependent variable. Table 8 is organized as Table 1 , a two-way panel model, while Table 9 mirrors Table 3, a dynamic panel model. Both Tables employ FOG as dependent variable. Table 10 instead presents the static panel model for $S I N D^{39}$.

These Tables suggest a blurred picture. The coefficient of size of the minority in the post-1967 sample has the expected sign only in a limited subset of regressions in Table 10, but never in Tables 8 and 9. Moreover, the coefficient on ethnic fractionalization is not statistically significant in most specifications for the South (or it is at 10 percent, but with the wrong sign). This same coefficient is insignificant (in fact very close to zero and switching sign) in the pre-1967 sample. The explanation for the wrong signs has often to do with the correlation between form of government and electoral rule (council-manager forms tend to employ at-large elections). Surely, further analysis of this issue (especially the institutional complementarity between form of government and electoral rule)

\footnotetext{
${ }^{39}$ The lack of pre-1980 observations for most components of SIND limit our analysis to the simple static model.
} 
is necessary, but on a first approximation it would appear that electoral rules more than forms of government respond to the racial composition of a city. Not surprisingly perhaps: electoral rules are the intuitive first line of defense against extensions of the democratic franchise.

\section{Conclusions}

Electoral rules are endogenous and evolve relatively quickly in response to changing underlying conditions. Minority representation depends on the ability of a majority bloc to adapt institutions to changing conditions and guaranteeing its supremacy. The experience of voting rights and electoral institutions in US cities, particularly in the South, is illuminating. Before the Voting Rights Acts of 1965, racial minorities were essentially disenfranchised in the US South. Therefore, the type of electoral institutions were irrelevant in determining the level of control of the white majority: a level of control that was almost absolute. The Voting Rights Act allowed racial minorities to enter into the political arena. The white majorities reacted, within the legal boundaries of the Voting Rights Act, by changing electoral rules as to minimize expected minority influence.

This evidence suggests how institutions (in this case electoral rules) evolve even rather quickly in response to changes in the environment and raises questions about empirical evidence that holds electoral institutions as exogenous. 


\section{References}

[1] Aghion, Philippe, Alberto Alesina, and Francesco Trebbi (2004) "Endogenous Political Institutions" Quarterly Journal of Economics, 119, May, 565612.

[2] Aghion, Philippe and Patrick Bolton (2003) "Incomplete Social Contracts" Journal of the European Economic Association,1, 38-67.

[3] Alesina, Alberto, Reza Baqir, and Caroline Hoxby (2004) "Political Jurisdictions in Heterogeneous Communities" Journal of Political Economy, 112, April, 348-396.

[4] Alesina, Alberto and Howard Rosenthal (1995) Partisan Politics, Divided Government, and the Economy (Cambridge University press, Cambridge, $\mathrm{UK})$.

[5] Alexander, Gerard (2005) "France: Reform-mongering between Majority Runoff and Proportionality", in Handbook of Electoral System Choice, by Josep M. Colomer (ed.) (Palgrave MacMillan, New York, N.Y.)

[6] Alt, James E. and Robert C. Lowry (1994) "Divided Government, Fiscal Institutions and Budget Deficits: Evidence from the States" American Political Science Review, 89, December, 811-828.

[7] Amy, Douglas J. (1993) Real Choices / New Voices: The Case for Proportional Representation Elections in the United States (Columbia University Press, New York, NY).

[8] Amy, Douglas J. (2002, second edition) Real Choices / New Voices: The Case for Proportional Representation Elections in the United States (Columbia University Press, New York, NY).

[9] Arellano, Manuel and Stephen Bond (1991) "Some Tests of Specification for Panel Data: Monte Carlo Evidence and an Application to Employment Equations" Review of Economics Studies, 58, January, 277-297. 
[10] Baqir, Reza (2002) "Districting and Government Overspending" Journal of Political Economy, 110, December, 1318-1354.

[11] Berry, Barbara L., and Thomas R. Dye (1979) "The Discriminatory Effects of At-Large Elections." Florida State University Law Review 7, 85-122.

[12] Bohn, Henning and Robert P. Inman (1996) "Balanced Budget Rules and Public Deficits: Evidence from US States" Carnegie Rochester Conference on Public Policies, 13-76.

[13] Buchanan, James M. and Gordon Tullock (1962) The Calculus of Consent: Logical Foundations of Constitutional Democracy (University of Michigan Press, Ann Arbor, MI).

[14] Cole, Leonard A. (1976) Blacks in Power: A Comparative Study of Black and White Elected Officials (Princeton University Press, Princeton, NJ).

[15] Colomer, Josep M. (2005) Handbook of Electoral System Choice, (Palgrave MacMillan, New York, N.Y.)

[16] Cox, Gary W. and Johnatan N. Katz (2002) Elbridge Gerry's Salamander (Cambridge University press, Cambridge, UK).

[17] Cutler, David, Edward Glaeser, and Jacob Vigdor (1999) "The Rise and Decline of the American Ghetto", Journal of Political Economy, 107, June, $455-506$.

[18] DeSantis, Victor and Tari Renner "Minority and Gender Representation In American County Legislatures: The Effect of Election Systems" in Rule, Wilma and Joseph F. Zimmerman (eds.) (1992) United States Electoral Systems (Greenwood Press, New York, US).

[19] Eple, Dennis and Thomas Romer (1991) "Mobility and Redistribution" Journal of Political Economy, 99, August, 828-858.

[20] Friedman, John N. and Richard Holden (2005) "Towards a Theory of Optimal Partisan Gerrymandering" Mimeograph, Harvard University. 
[21] Grofman, Bernard, Lisa Handley, and Richard Niemi (1992) Minority Representation and the Quest for Voting Equality (Cambridge University Press, New York, NY).

[22] Hacker, Andrew (1992) Two nations: Black and White, Separate, Hostile, Unequal (Scribner's, New York, US).

[23] Hayek, Friedrich A. (1960) The Constitution of Liberty (University of Chicago Press, Chicago, Ill).

[24] Huckfeld, Robert, and Carol Weitzel Kohfeld (1989) Race and the Decline of Class in American Politics (University of Illinois Press, Urbana, Ill).

[25] Imbs, Jean and Romain Wacziarg (2003) "Stages of Diversification" American Economic Review, 93, March, 63-86.

[26] Karning, Albert K. and Susan Welch (1982) "Electoral Structure and Black Representation on City Councils" Social Science Quarterly, 63, March, 99114.

[27] Kousser, Morgan J. (1999) Color-blind Injustice: Minority Voting Rights and the Undoing of the Second Reconstruction (University of North Carolina Press, Chapel Hill, NC).

[28] Kreuzer, Marcus (2005) "Germany: Partisan Engineering of Personalized Proportional Representation", in Handbook of Electoral System Choice, by Josep M. Colomer (ed.) (Palgrave MacMillan, New York, N.Y.)

[29] Lijphart, Arend (1994) Electoral Systems and Party Systems: a Study of 27 Democracies (Oxford University Press, New York, NY).

[30] Mulligan, Casey B., Richard Gil, and Xavier Sala-i-Martin (2004) " Do Democracies Have Different Public Policies than Nondemocracies?" Journal of Economic Perspectives, 18, winter, 51-74.

[31] Myrdal, Gunnar (1944) An American Dilemma (Harper \& Row Publishers, New York, NY). 
[32] Pande, Rohini (2003) "Can Mandate Political Representation Increase Policy Influence for Disadvantaged Minorities? Theory and Evidence from India" American Economic Review, 93, 1132-1151.

[33] Persson, Torsten and Guido Tabellini (2003) The Economics Effects of Constitutions (MIT Press, Cambridge, MA).

[34] Poterba, James M. (1994) "State Response on Fiscal Crises: The Effects of Budgetary Institutions on Policies", Journal of Political Economy, 102, August, 799-821.

[35] Riker, William (1986) The Art of Political Manipulation (Yale University Press, New Haven, CT).

[36] Strumpf, S. Koleman and Felix Oberholzer-Gee (2002) "Endogenous Policy Decentralization: Testing the Central Tenet of Economic Federalism" Journal of Political Economy, 110, February, 1-36.

[37] Voigt, Stefan (1997) "Positive Constitutional Economics: A Survey" Public Choice, 90, March,11-53.

[38] Wilson,William J. (1996) When Work Disappear: The World of the New Urban Poor (Knopf, New York, NY)

\section{Appendix: Sample selection}

In this section we aim at inspecting mayor selection issues regarding the sample of municipalities employed in the main analysis (the ICMA respondents sample).

First, we inspect differences in the distribution of population and economic covariates between the main sample (all US and South municipalities) employed in the analysis (that is the ICMA respondents sample) and the whole U.S. Census of population sample for the 1980-2000 period. This comparison is finalized at qualitatively assessing how representative is our sample of the whole population of U.S. municipalities. Significant differences in the moments of the 
distributions of the covariates would indicate non-random sampling from the underlying population of U.S. municipalities.

Second, we compare population and economic covariates between the main sample (all US and South) employed in the analysis and the universe of cities to which the ICMA initially mailed the survey in year 2000. This comparison is finalized at assessing self-selection of the respondents. Significant differences in the moments of the distributions of the covariates would indicate non-randomness of non-response patterns.

Third, sample selection is also investigated for the years 1930-1970, but limited to States in the South.

Table (AI) presents qualitative evidence of sample selection. The ICMA sample covers 13 percent of municipalities reported in the U.S. Census of Population for 1980, 11 percent in 1990, and 8 percent in year 2000. ICMA respondent municipalities tend to be more ethnically divided, larger in terms of total population, and richer in terms of median income at the city level. All two-sample t tests of difference in the means across the whole Census and ICMA samples for each covariate reject equality in means significantly (below 1 percent confidence level $\left.{ }^{40}\right)$.

One reason for selection arises naturally from ICMA sample construction strategy. Municipalities included in the U.S. Census above 2500 population are included in the ICMA survey "universe" (Municipal Year Book, 2003). Of those below 2500 population, only municipalities affiliated to ICMA are included. For sample year 2000 ICMA respondent municipalities below 2500 amount to about 11 percent of the whole sample (376 municipalities out of a total 4193). Similar proportions are found in the 1980 and 1990 samples.

Unfortunately, such explanations do not account for selection completely. Even considering the Census and ICMA sub-samples with population above

\footnotetext{
${ }^{40}$ Both year by year and pooled two-sample t test for difference in means were run, for a total of twelve tests (3 years: 1980-1990-2000 plus the pooled sample times 3 covariates: ethnic, pop, income). We allow for unequal variances across sub-samples. All tests are available from the authors.
} 
2500 and comparing the two sub-samples, significant differences in the mean of the covariates do not disappear in some cases (population size).

Table (AII) presents little evidence of response selection for the sample of non-respondents and respondents in the 2001 ICMA Municipal Form of Government Survey. The choice of the year is dictated by the fact that ICMA maintains historical record of the whole list of municipalities in their "universe" for their 1996 and 2001 Form of Government surveys only. There was no corresponding equivalent list of surveyed municipalities for 1981 and 1991.

The percentage of responses received in 2001 for which data is about 54 percent, a measure conforming to previous survey's response rates as well. ICMA respondent and non-respondent municipalities tend to be equally ethnically divided and to have the same total population. Two-sample $t$ tests for differences in means reject the hypothesis of equality at standard confidence levels $(1,5$, and 10 percent). However, median income of ICMA non-respondent municipalities is lower than income of respondents in a statistically significant fashion. One possible explanation could be the availability of more administrative resources in relatively richer communities, allowing for more effective handling of survey response and similar incidental administrative tasks.

Table (AIII) reports summary statistics for both the (matched) ICMA sample obtained from the ICMA Municipal Year Book (various years) and whole Census sample for the period 1930-1970. Data for this period were collected only for cities in the South (see Data Appendix for detailed data sources).

Again as for the 1980-2000 samples reported in Table (AI) the sampling strategy adopted by the ICMA (and feasibility issues) presents statistically significant difference from the Census samples. ICMA selects larger (and therefore more fragmented) and richer cities for its analysis (see details on samples sizes in the Data Appendix). Again, t tests for differences in means provide formal support to the inspection of Table (AIII). 
Table I

Size of Minority and City Electoral Rule: Within-city variation

\begin{tabular}{|c|c|c|c|c|c|c|}
\hline Estimator: & $\begin{array}{l}\text { Fixed } \\
\text { Effects }\end{array}$ & $\begin{array}{l}\text { Fixed } \\
\text { Effects } \\
\text { South, } \\
\text { Cities > } \\
2500\end{array}$ & $\begin{array}{l}\text { Fixed } \\
\text { Effects }\end{array}$ & $\begin{array}{l}\text { Fixed } \\
\text { Effects }\end{array}$ & $\begin{array}{l}\text { Fixed } \\
\text { Effects }\end{array}$ & $\begin{array}{l}\text { Fixed } \\
\text { Effects }\end{array}$ \\
\hline \multicolumn{7}{|c|}{$\begin{array}{c}\text { Panel (a): Post } 1967 \\
\text { Dependent variable: Fraction of councilmen elected by district }\end{array}$} \\
\hline & $(1)$ & $(2)$ & (3) & $(4)$ & (5) & (6) \\
\hline Frac. Minority & $\begin{array}{l}-0.885 \\
{[0.308]^{\star \star \star}}\end{array}$ & $\begin{array}{l}-0.943 \\
{[0.313]^{\star \star \star}}\end{array}$ & $\begin{array}{l}-0.877 \\
{[0.308]^{\star \star \star}}\end{array}$ & $\begin{array}{l}-0.818 \\
{[0.325]^{\star \star}}\end{array}$ & $\begin{array}{l}-0.565 \\
{[0.198]^{\star \star \star}}\end{array}$ & $\begin{array}{l}-0.453 \\
{[0.195]^{\star \star}}\end{array}$ \\
\hline$(\text { Frac. Minority })^{\wedge} 2$ & $\begin{array}{l}1.514 \\
{[0.475]^{\star \star \star}}\end{array}$ & $\begin{array}{l}1.819 \\
{[0.491]^{\star \star \star}}\end{array}$ & $\begin{array}{l}1.532 \\
{[0.478]^{\star \star \star}}\end{array}$ & $\begin{array}{l}1.385 \\
{[0.462]^{\star \star *}}\end{array}$ & $\begin{array}{l}0.964 \\
{[0.279]^{\star \star \star}}\end{array}$ & $\begin{array}{l}0.777 \\
{[0.263]^{\star \star \star}}\end{array}$ \\
\hline Log(City Population) & $\begin{array}{l}0.002 \\
{[0.038]}\end{array}$ & $\begin{array}{l}0.015 \\
{[0.039]}\end{array}$ & $\begin{array}{l}-0.007 \\
{[0.041]}\end{array}$ & $\begin{array}{l}-0.017 \\
{[0.043]}\end{array}$ & $\begin{array}{l}0.013 \\
{[0.023]}\end{array}$ & $\begin{array}{l}-0.003 \\
{[0.025]}\end{array}$ \\
\hline Log(Median Income) & & & $\begin{array}{l}0.056 \\
{[0.093]}\end{array}$ & $\begin{array}{l}0.022 \\
{[0.100]}\end{array}$ & & $\begin{array}{l}0.011 \\
{[0.054]}\end{array}$ \\
\hline State trend & & & & Included & & Included \\
\hline Observations & 4011 & 3723 & 4010 & 4010 & 12413 & 12412 \\
\hline Number of cities & 1914 & 1746 & 1914 & 1914 & 6526 & 6526 \\
\hline R-squared & 0.71 & 0.71 & 0.71 & 0.74 & 0.84 & 0.86 \\
\hline \multicolumn{7}{|c|}{$\begin{array}{c}\text { Panel (b): Pre } 1967 \\
\text { lent variable: Fraction of councilmen elected by district }\end{array}$} \\
\hline & (1) & $(2)$ & (3) & (4) & & \\
\hline Frac. Minority & $\begin{array}{l}0.421 \\
{[0.548]}\end{array}$ & $\begin{array}{l}0.584 \\
{[0.858]}\end{array}$ & $\begin{array}{l}1.233 \\
{[1.287]}\end{array}$ & $\begin{array}{l}1.136 \\
{[1.276]}\end{array}$ & & \\
\hline$($ Frac. Minority)^2 & $\begin{array}{l}-0.439 \\
{[0.638]}\end{array}$ & $\begin{array}{l}-0.754 \\
{[1.385]}\end{array}$ & $\begin{array}{l}-1.722 \\
{[1.932]}\end{array}$ & $\begin{array}{l}-1.958 \\
{[1.941]}\end{array}$ & & \\
\hline Log(City Population) & $\begin{array}{l}0.017 \\
{[0.041]}\end{array}$ & $\begin{array}{l}0.021 \\
{[0.041]}\end{array}$ & $\begin{array}{l}0.084 \\
{[0.058]}\end{array}$ & $\begin{array}{l}0.095 \\
{[0.060]}\end{array}$ & & \\
\hline Log(Median Income) & & & $\begin{array}{l}-0.113 \\
{[0.065]^{*}}\end{array}$ & $\begin{array}{l}-0.058 \\
{[0.061]}\end{array}$ & & \\
\hline State trend & & & & Included & & \\
\hline Observations & 2388 & 2382 & 2041 & 2041 & & \\
\hline Number of cities & 968 & 964 & 966 & 966 & & \\
\hline R-squared & 0.71 & 0.71 & 0.73 & 0.76 & & \\
\hline
\end{tabular}

Notes: Standard errors in brackets below coefficients. ${ }^{*}$ significant at $10 \%$; ${ }^{* *}$ significant at $5 \%$; ${ }^{* \star}$ significant at $1 \%$. In panel (a) and (b) standard errors are clustered at the city level. All regressions include year fixed effects. Panel (a) covers the period 1970-2000. Panel (b) covers the period 1930-1970. 


\section{Table II}

Size of Minority and City Electoral Rule: Within-city variation

\begin{tabular}{|c|c|c|c|c|c|}
\hline Estimator: & $\begin{array}{l}\text { Condition- } \\
\text { al Logit }\end{array}$ & $\begin{array}{l}\text { Condition- } \\
\text { al Logit } \\
\text { South, } \\
\text { Cities > } \\
2500\end{array}$ & $\begin{array}{l}\text { Condition- } \\
\text { al Logit }\end{array}$ & $\begin{array}{l}\text { Condition- } \\
\text { al Logit }\end{array}$ & $\begin{array}{l}\text { Condition- } \\
\text { al Logit }\end{array}$ \\
\hline \multicolumn{6}{|c|}{$\begin{array}{c}\text { Panel (a): Post } 1967 \\
\text { endent variable: Single district elections }\end{array}$} \\
\hline & (1) & $(2)$ & (3) & $(4)$ & (5) \\
\hline Frac. Minority & $\begin{array}{l}-11.422 \\
{[3.459]^{\star \star \star}}\end{array}$ & $\begin{array}{l}-11.604 \\
{[3.503]^{\star \star \star}}\end{array}$ & $\begin{array}{l}-11.288 \\
{[3.458]^{\star \star \star}}\end{array}$ & $\begin{array}{l}-5.184 \\
{[4.890]}\end{array}$ & $\begin{array}{l}-8.476 \\
{[2.674]^{\star \star \star}}\end{array}$ \\
\hline$(\text { Frac. Minority })^{\wedge} 2$ & $\begin{array}{l}23.753 \\
{[5.574]^{\star \star \star}}\end{array}$ & $\begin{array}{l}24.318 \\
{[5.660]^{\star \star *}}\end{array}$ & $\begin{array}{l}23.842 \\
{[5.574]^{\star \star \star}}\end{array}$ & $\begin{array}{l}19.253 \\
{[7.481]^{\star \star}}\end{array}$ & $\begin{array}{l}18.359 \\
{[4.214]^{\star \star \star}}\end{array}$ \\
\hline Log(City Population) & $\begin{array}{l}0.486 \\
{[0.430]}\end{array}$ & $\begin{array}{l}0.491 \\
{[0.437]}\end{array}$ & $\begin{array}{l}0.389 \\
{[0.436]}\end{array}$ & $\begin{array}{l}0.016 \\
{[0.626]}\end{array}$ & $\begin{array}{l}0.193 \\
{[0.289]}\end{array}$ \\
\hline $\begin{array}{l}\text { Log(Median Income) } \\
\text { State trend }\end{array}$ & & & $\begin{array}{l}0.778 \\
{[0.933]}\end{array}$ & $\begin{array}{l}0.695 \\
\text { [1.335] } \\
\text { Included }\end{array}$ & \\
\hline Observations & 641 & 620 & 641 & 641 & 1305 \\
\hline Number of cities & 214 & 205 & 214 & 214 & 493 \\
\hline \multicolumn{6}{|c|}{$\begin{array}{c}\text { Panel (b): Pre 1967 } \\
\text { Dependent variable: Single district elections }\end{array}$} \\
\hline & $(1)$ & $(2)$ & (3) & $(4)$ & \\
\hline Frac. Minority & $\begin{array}{l}10.805 \\
{[6.815]}\end{array}$ & $\begin{array}{l}10.805 \\
{[6.815]}\end{array}$ & $\begin{array}{l}10.345 \\
{[7.416]}\end{array}$ & $\begin{array}{l}11.631 \\
{[9.969]}\end{array}$ & \\
\hline$(\text { Frac. Minority })^{\wedge} 2$ & $\begin{array}{l}-12.233 \\
{[10.265]}\end{array}$ & $\begin{array}{l}-12.233 \\
{[10.265]}\end{array}$ & $\begin{array}{l}-12.177 \\
{[10.992]}\end{array}$ & $\begin{array}{l}-19.614 \\
{[14.690]}\end{array}$ & \\
\hline Log(City Population) & $\begin{array}{l}-0.068 \\
{[0.422]}\end{array}$ & $\begin{array}{l}-0.068 \\
{[0.422]}\end{array}$ & $\begin{array}{l}0.453 \\
{[0.501]}\end{array}$ & $\begin{array}{l}0.865 \\
{[0.772]}\end{array}$ & \\
\hline Log(Median Income) & & & $\begin{array}{l}-1.753 \\
{[0.967]^{*}}\end{array}$ & $\begin{array}{l}-1.698 \\
{[1.407]}\end{array}$ & \\
\hline State trend & & & & & \\
\hline Observations & 529 & 529 & 404 & 404 & \\
\hline Number of cities & 163 & 163 & 147 & 147 & \\
\hline
\end{tabular}

Notes: Standard errors in brackets below coefficients. * significant at 10\%; ** significant at $5 \%$; $* \star *$ significant at $1 \%$. All regressions include year fixed effects. Panel (a) covers the period 1970-2000. Panel (b) covers the period 1930-1970. 
Table III

Size of Minority and City Electoral Rule: Within-city variation

\begin{tabular}{|c|c|c|c|}
\hline Estimator: & $\begin{array}{l}\text { Arellano- } \\
\text { Bond } \\
\text { GMM }\end{array}$ & $\begin{array}{l}\text { Arellano- } \\
\text { Bond } \\
\text { GMM } \\
\text { South, } \\
\text { Cities > } \\
2500\end{array}$ & $\begin{array}{l}\text { Arellano- } \\
\text { Bond } \\
\text { GMM }\end{array}$ \\
\hline \multicolumn{4}{|c|}{$\begin{array}{c}\text { Panel (a): Post } 1967 \\
\text { Dependent variable: Fraction of councilmen elected by district }\end{array}$} \\
\hline & $(1)$ & $(2)$ & (3) \\
\hline Lag Single District & $\begin{array}{l}0.313 \\
{[0.056]^{\star \star \star}}\end{array}$ & $\begin{array}{l}0.311 \\
{[0.055]^{\star \star \star}}\end{array}$ & $\begin{array}{l}0.29 \\
{[0.057]^{\star \star \star}}\end{array}$ \\
\hline Frac. Minority & $\begin{array}{l}-1.644 \\
{[0.712]^{\star \star}}\end{array}$ & $\begin{array}{l}-1.654 \\
{[0.724]^{\star *}}\end{array}$ & $\begin{array}{l}-2.113 \\
{[0.635]^{\star \star *}}\end{array}$ \\
\hline$(\text { Frac. Minority })^{\wedge} 2$ & $\begin{array}{l}2.649 \\
{[1.002]^{\star \star \star}}\end{array}$ & $\begin{array}{l}2.822 \\
{[0.972]^{\star \star \star}}\end{array}$ & $\begin{array}{l}1.838 \\
{[0.706]^{\star \star \star}}\end{array}$ \\
\hline Log(City Population) & $\begin{array}{l}-0.342 \\
{[0.258]}\end{array}$ & $\begin{array}{l}-0.33 \\
{[0.275]}\end{array}$ & $\begin{array}{l}-0.538 \\
{[0.236]^{\star \star}}\end{array}$ \\
\hline $\begin{array}{l}\text { Second Order Serial } \\
\text { value }\end{array}$ & 0.140 & 0.140 & 0.196 \\
\hline $\mathrm{J}$ test $\mathrm{p}$-value & 0.123 & 0.160 & 0.021 \\
\hline Observations & 1506 & 1489 & 2508 \\
\hline Number of cities & 797 & 782 & 1799 \\
\hline
\end{tabular}

Panel (b): Pre 1967

Dependent variable: Fraction of councilmen elected by district

(1)

(2)

$\begin{array}{lll}\text { Lag Single District } & 0.751 & 0.751 \\ & {[0.109]^{\star \star *}} & {[0.109]^{\star \star \star}} \\ \text { Frac. Minority } & 1.829 & 1.829 \\ & {[5.259]} & {[5.259]} \\ \text { (Frac. Minority) }^{\wedge} 2 & -3.634 & -3.634 \\ & {[7.928]} & {[7.928]} \\ \text { Log(City Population) } & 0.272 & 0.272 \\ & {[0.319]} & {[0.319]}\end{array}$

Second Order Serial Correlation $\mathrm{p}$ -

\begin{tabular}{lll} 
value & 0.07 & 0.07 \\
$\mathrm{~J}$ test $\mathrm{p}$-value & 0.997 & 0.997 \\
Observations & 891 & 891 \\
Number of cities & 462 & 462 \\
\hline \hline
\end{tabular}

Notes: Robust standard errors in brackets below coefficients. * significant at 10\%; ** significant at 5\%; *** significant at $1 \%$. Lag Single District is the the first lag of the dependent variable. All regressions include year fixed effects. Panel (a) covers the period 1970-2000. Panel (b) covers the period 1930-1970. Both ethnic fractionalization and population are treated as endogenous variables. The maximum number of lags used for instrumenting them is 2 . 
Table IV

Change in slope and t-stat of local within regressions of single-district on fraction of minority $(\pi)$ over the range of $\pi$.

\begin{tabular}{|c|c|c|}
\hline \\
\hline \multirow{2}{*}{ South } & Slope & t-stat \\
\hline & (1) & (2) \\
\hline \multirow[t]{2}{*}{ post 1967} & 4.596 & 2.850 \\
\hline & {$[0.797]^{\star \star \star}$} & {$[0.473]^{\star \star \star}$} \\
\hline \multirow[t]{2}{*}{ South } & Slope & t-stat \\
\hline & (1) & (2) \\
\hline pre 1967 & $\begin{array}{l}0.165 \\
{[0.353]}\end{array}$ & $\begin{array}{l}0.897 \\
{[0.926]}\end{array}$ \\
\hline \multicolumn{3}{|c|}{$\begin{array}{l}\text { Notes: Column (1) reports coefficients } \\
\text { and standard errors corresponding to } \\
\text { regression of locally estimated } \\
\text { coefficients of single-district on fraction } \\
\text { of minority on the corresponding mid- } \\
\text { sample fraction of minority. Column (2) } \\
\text { employs the corresponding t-statistic. } \\
\text { Robust standard errors are in brackets } \\
\text { below coefficients. * significant at } 10 \% \text {; } \\
\star \star \\
\text { * significant at } 5 \% \text {; }{ }^{\star \star} \text { significant at } \\
1 \% \text {. Regressions include a constant } \\
\text { (not reported). See text for local } \\
\text { sample details. }\end{array}$} \\
\hline
\end{tabular}


Table V

City Electoral Rule and Minority Representation: Cross-sectional and Within-city variation

\begin{tabular}{|c|c|c|c|c|c|c|c|}
\hline Sample: & South & $\begin{array}{l}\text { South, } \\
\text { Cities > } \\
2500\end{array}$ & All U.S. & South & South & $\begin{array}{l}\text { South, } \\
\text { Cities > } \\
2500\end{array}$ & $\begin{array}{l}\text { South } \\
\text { (Black } \\
\text { only) }\end{array}$ \\
\hline \multicolumn{8}{|c|}{$\begin{array}{c}\text { Panel (a): OLS } \\
\text { Dependent variable: Representaional ratio }\end{array}$} \\
\hline & (1) & $(2)$ & $(3)$ & (4) & (5) & (6) & (7) \\
\hline Single-District & $\begin{array}{l}0.13 \\
{[0.041]^{\star \star *}}\end{array}$ & $\begin{array}{l}0.125 \\
{[0.043]^{\star \star * *}}\end{array}$ & $\begin{array}{l}0.015 \\
{[0.018]}\end{array}$ & $\begin{array}{l}0.205 \\
{[0.067]^{\star \star \star}}\end{array}$ & 0.169 & 0.173 & $\begin{array}{l}0.299 \\
{[0,099]^{*} \star \star}\end{array}$ \\
\hline (Single-Distr. * Frac. Min.) & & & & $\begin{array}{l}-0.333 \\
{[0.159]^{\star \star}}\end{array}$ & $\begin{array}{l}-0.289 \\
{[0.157]^{\star}}\end{array}$ & $\begin{array}{l}-0.315 \\
{[0.167]^{\star}}\end{array}$ & $\begin{array}{l}-0.38 \\
{[0.163]^{\star \star}}\end{array}$ \\
\hline \multirow[t]{2}{*}{ Frac. Minority } & & & & 0.802 & 0.586 & 0.533 & 0.824 \\
\hline & & & & {$[0.077]^{\star \star \star}$} & {$[0.081]^{\star \star \star}$} & {$[0.091]^{\star \star \star}$} & {$[0.066]^{\star \star \star}$} \\
\hline \multirow[t]{2}{*}{ Log(City Population) } & 0.106 & 0.117 & 0.102 & 0.08 & 0.096 & 0.108 & 0.072 \\
\hline & {$[0.015]^{\star \star \star}$} & {$[0.016]^{\star \star \star}$} & {$[0.007]^{\star \star \star}$} & {$[0.014]^{\star \star \star}$} & {$[0.015]^{\star \star \star}$} & {$[0.017]^{\star \star \star}$} & {$[0.012]^{\star \star \star}$} \\
\hline \multirow[t]{2}{*}{ Log(Median Income) } & -0.362 & -0.45 & -0.338 & & -0.254 & -0.352 & \\
\hline & {$[0.062]^{\star \star \star}$} & {$[0.064]^{\star \star \star}$} & {$[0.021]^{\star \star \star}$} & & {$[0.068]^{\star \star \star}$} & {$[0.072]^{\star \star \star}$} & \\
\hline Observations & 3039 & 2767 & 11113 & 3039 & 3039 & 2767 & 2875 \\
\hline \multirow[t]{3}{*}{ R-squared } & 0.07 & 0.08 & 0.06 & 0.07 & 0.08 & 0.09 & 0.09 \\
\hline & Depen & $\begin{array}{l}\text { Panel (b): } \\
\text { dent varial }\end{array}$ & $\begin{array}{l}\text { City Fixed } \\
\text { le: Represe }\end{array}$ & $\begin{array}{l}\text { Effects } \\
\text { entaional ra }\end{array}$ & & & \\
\hline & $(1)$ & $(2)$ & (3) & $(4)$ & (5) & (6) & (7) \\
\hline \multirow[t]{2}{*}{ Single-District } & 0.354 & 0.377 & 0.204 & 0.298 & 0.297 & 0.36 & 0.221 \\
\hline & [0.091] & & & [0.196] & [0.196] & {$[0.174]^{\star \star}$} & [0.163] \\
\hline (Single-Distr. * Frac. Min.) & & & & $\begin{array}{l}0.211 \\
{[0.472]}\end{array}$ & $\begin{array}{l}0.212 \\
{[0.472]}\end{array}$ & $\begin{array}{l}0.063 \\
{[0.436]}\end{array}$ & $\begin{array}{l}0.385 \\
{[0.4201}\end{array}$ \\
\hline \multirow[t]{2}{*}{ Frac. Minority } & & & & -0.643 & -0.579 & -0.626 & -0.568 \\
\hline & & & & {$[0.380]^{\star}$} & [0.380] & {$[0.436]$} & {$[0.354]$} \\
\hline \multirow[t]{2}{*}{ Log(City Population) } & -0.006 & 0.012 & 0.072 & 0.033 & 0.013 & 0.04 & 0.012 \\
\hline & [0.097] & [0.114] & {$[0.070]$} & {$[0.096]$} & [0.099] & [0.118] & {$[0.103]$} \\
\hline \multirow[t]{2}{*}{ Log(Median Income) } & 0.215 & 0.214 & 0.000 & & 0.124 & 0.107 & \\
\hline & [0.182] & {$[0.202]$} & [0.110] & & [0.183] & {$[0.207]$} & \\
\hline Observations & 3039 & 2767 & 11113 & 3039 & 3039 & 2767 & 2875 \\
\hline Number of cities & 1642 & 1482 & 6158 & 1642 & 1642 & 1482 & 1570 \\
\hline R-squared & 0.76 & 0.76 & 0.71 & 0.76 & 0.76 & 0.76 & 0.69 \\
\hline
\end{tabular}

Notes: Robust standard errors are in brackets below coefficients. * significant at $10 \%$; ${ }^{* *}$ significant at $5 \%$; *** significant at $1 \%$. Standard errors are clustered at the city level. All regressions include year fixed effects. Sample coverage: period 1980-2000. The representational ratio is the fraction of non-white (black in column 7 of both panels) councilmen in the council divided by the fraction of the population that is non-white (black in column 7). 
Table VI: Characteristics of Cities Changing Electoral Rule Under Voting Rights Act Preclearance Condition (by decade)

\begin{tabular}{|c|c|c|c|c|c|c|c|c|c|}
\hline \multicolumn{10}{|c|}{ 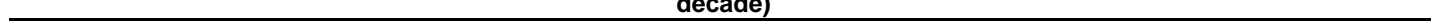 } \\
\hline \multicolumn{10}{|c|}{ Period 1970-1980 } \\
\hline \multicolumn{5}{|c|}{ Voting Rights Act - South States fully covered } & \multicolumn{5}{|c|}{ Voting Rights Act - All South States with some coverage } \\
\hline \multicolumn{5}{|c|}{ Subsample Decreasing SINGLE DISTRICT } & \multicolumn{5}{|c|}{ Subsample Decreasing SINGLE DISTRICT } \\
\hline Variable & Obs & Median & $\begin{array}{l}- \text { Binom. I } \\
\text { [95\% Conf }\end{array}$ & $\begin{array}{l}\text { Interp. -- } \\
\text { f. Interval] }\end{array}$ & Variable & Obs & Median & $\begin{array}{l}\text {-- Binom. } \\
\text { [95\% Con }\end{array}$ & $\begin{array}{l}\text { Interp. -- } \\
\text { f. Interval] }\end{array}$ \\
\hline Ethnic(t-10) & 21 & 0.166378 & .0693809 & .3390113 & Ethnic(t-10) & 33 & 0.194508 & .1245294 & .3270092 \\
\hline Ethnic(t) & 21 & 0.264663 & .1964563 & .4114405 & Ethnic $(\mathrm{t})$ & 33 & 0.293621 & .2108922 & .40505 \\
\hline Frac. Black(t-10) & 21 & 0.089928 & .0348796 & .21687 & Frac. Black(t-10) & 33 & 0.10792 & .0529065 & .203928 \\
\hline Frac. Black(t) & 21 & 0.098622 & .0468097 & .2428612 & Frac. Black(t) & 33 & 0.101751 & .0556345 & .2656905 \\
\hline Frac. Minrty(t-10) & 21 & 0.091503 & .0359641 & .2196268 & Frac. Minrty(t-10) & 33 & 0.109021 & .0659537 & .2053961 \\
\hline Frac. Minrty(t) & 21 & 0.155286 & .1083713 & .2895482 & Frac. Minrty(t) & 33 & 0.168885 & .1170527 & .2795585 \\
\hline \multicolumn{5}{|c|}{ Subsample Increasing SINGLE DISTRICT } & \multicolumn{5}{|c|}{ Subsample Increasing SINGLE DISTRICT } \\
\hline Variable & Obs & Median & $\begin{array}{l}- \text { Binom. I } \\
\text { [95\% Conf }\end{array}$ & $\begin{array}{l}\text { Interp. -- } \\
\text { f. Interval] }\end{array}$ & Variable & Obs & Median & $\begin{array}{l}\text {-- Binom. } \\
{[95 \% \text { Con }}\end{array}$ & $\begin{array}{l}\text { Interp. -- } \\
\text { f. Interval] }\end{array}$ \\
\hline Ethnic(t-10) & 47 & 0.399117 & .3215923 & .4472221 & Ethnic(t-10) & 60 & 0.373299 & .3035595 & .4265772 \\
\hline Ethnic(t) & 47 & 0.447266 & .3823418 & .4795029 & Ethnic(t) & 60 & 0.429007 & .3687487 & .4599396 \\
\hline Frac. Black(t-10) & 47 & 0.273235 & .1994838 & .3360678 & Frac. Black(t-10) & 60 & 0.244803 & .1787823 & .3061703 \\
\hline Frac. Black(t) & 47 & 0.284737 & .2312183 & .3751268 & Frac. Black(t) & 60 & 0.25262 & .1942273 & .3326913 \\
\hline Frac. Minrty(t-10) & 47 & 0.274588 & .2008917 & .3368007 & Frac. Minrty(t-10) & 60 & 0.24784 & .1839426 & .3074507 \\
\hline Frac. Minrty(t) & 47 & 0.301235 & .2507999 & .3861642 & Frac. Minrty $(\mathrm{t})$ & 60 & 0.293116 & .2378248 & .3573126 \\
\hline \multicolumn{10}{|c|}{ Period 1980-1990 } \\
\hline \multicolumn{5}{|c|}{ Voting Rights Act - South States fully covered } & \multicolumn{5}{|c|}{ Voting Rights Act - All South States with some coverage } \\
\hline \multicolumn{5}{|c|}{ Subsample Decreasing SINGLE DISTRICT } & \multicolumn{5}{|c|}{ Subsample Decreasing SINGLE DISTRICT } \\
\hline Variable & Obs & Median & $\begin{array}{l}-- \text { Binom. I } \\
\text { [95\% Conf }\end{array}$ & $\begin{array}{l}\text { Interp. -- } \\
\text { f. Interval] }\end{array}$ & Variable & Obs & Median & $\begin{array}{l}\text {-- Binom. } \\
{[95 \% \text { Con }}\end{array}$ & $\begin{array}{l}\text { Interp. -- } \\
\text { f. Interval] }\end{array}$ \\
\hline Ethnic(t-10) & 17 & 0.217387 & .1443274 & .3484081 & Ethnic(t-10) & 30 & 0.231083 & .1419625 & .3267115 \\
\hline Ethnic(t) & 17 & 0.315041 & .2239849 & .4026764 & Ethnic(t) & 30 & 0.312536 & .2282883 & .3680777 \\
\hline Frac. Black(t-10) & 17 & 0.089428 & .0521425 & .160876 & Frac. Black(t-10) & 30 & 0.094368 & .0548517 & .1727142 \\
\hline Frac. Black(t) & 17 & 0.128993 & .043128 & .1980163 & Frac. Black(t) & 30 & 0.143769 & .0895188 & .1661797 \\
\hline Frac. Minrty(t-10) & 17 & 0.124092 & .0770264 & .2160449 & Frac. Minrty(t-10) & 30 & 0.130488 & .0766336 & .2023592 \\
\hline Frac. Minrty(t) & 17 & 0.182511 & .1253335 & .2545895 & Frac. Minrty(t) & 30 & 0.182582 & .1275517 & .2312641 \\
\hline \multicolumn{5}{|c|}{ Subsample Increasing SINGLE DISTRICT } & \multicolumn{5}{|c|}{ Subsample Increasing SINGLE DISTRICT } \\
\hline Variable & Obs & Median & $\begin{array}{l}\text {-- Binom. I } \\
\text { [95\% Conf }\end{array}$ & $\begin{array}{l}\text { Interp. -- } \\
\text { f. Interval] }\end{array}$ & Variable & Obs & Median & $\begin{array}{l}\text {-- Binom. } \\
{[95 \% \text { Con }}\end{array}$ & $\begin{array}{l}\text { Interp. -- } \\
\text { f. Interval] }\end{array}$ \\
\hline Ethnic(t-10) & 65 & 0.347108 & .3075647 & .3947446 & Ethnic(t-10) & 86 & 0.368366 & .3349446 & .4078901 \\
\hline Ethnic(t) & 67 & 0.40034 & .3682412 & .4260964 & Ethnic(t) & 88 & 0.406157 & .3725483 & .4366212 \\
\hline Frac. Black(t-10) & 65 & 0.165714 & .1039453 & .2080752 & Frac. Black(t-10) & 86 & 0.19266 & .1584294 & .2327117 \\
\hline Frac. Black(t) & 67 & 0.179089 & .144787 & .2106473 & Frac. Black(t) & 88 & 0.200002 & .1642106 & .2602224 \\
\hline Frac. Minrty(t-10) & 65 & 0.219606 & .1854808 & .2644502 & Frac. Minrty(t-10) & 86 & 0.229868 & .2097406 & .2767364 \\
\hline Frac. Minrty(t) & 67 & 0.256799 & .2300964 & .2818591 & Frac. Minrty(t) & 88 & 0.272591 & .2359458 & .3136792 \\
\hline \multicolumn{10}{|c|}{ Period 1990-2000 } \\
\hline \multicolumn{5}{|c|}{ Voting Rights Act - South States fully covered } & Voting Rights A & $\Delta \| c c^{\prime}$ & outh States & vitu some & coverage \\
\hline Subsample Decre & $n g$ SIN & VGLE DISTI & RICT & & Subsample Decr & $n g$ SIN & VGLE DIST & $R I C T$ & \\
\hline Variable & Obs & Median & $\begin{array}{l}\text {-- Binom. I } \\
\text { [95\% Conf }\end{array}$ & $\begin{array}{l}\text { Interp. -- } \\
\text { f. Interval] }\end{array}$ & Variable & Obs & Median & $\begin{array}{l}- \text { Binom. } \\
\text { [95\% Con }\end{array}$ & $\begin{array}{l}\text { Interp. -- } \\
\text { f. Interval] }\end{array}$ \\
\hline Ethnic(t-10) & 18 & 0.395447 & .3501902 & .4837628 & Ethnic(t-10) & 21 & 0.406057 & .3756696 & .4828541 \\
\hline Ethnic(t) & 20 & 0.441584 & .3721584 & .4774563 & Ethnic(t) & 23 & 0.455352 & .3991932 & .5043442 \\
\hline Frac. Black(t-10) & 18 & 0.113582 & .0628309 & .255522 & Frac. Black(t-10) & 21 & 0.179089 & .0732573 & .2642068 \\
\hline Frac. Black(t) & 20 & 0.176006 & .0598381 & .2968652 & Frac. Black(t) & 23 & 0.239966 & .0882167 & .3533759 \\
\hline Frac. Minrty(t-10) & 18 & 0.255387 & .2146877 & .3557325 & Frac. Minrty(t-10) & 21 & 0.261304 & .2340239 & .3530408 \\
\hline Frac. Minrty(t) & 20 & 0.29508 & .2291953 & .3703512 & Frac. Minrty(t) & 23 & 0.324099 & .2464538 & .4250296 \\
\hline Subsample Increa & $g \operatorname{SIN}$ & $\overline{G L E ~ D I S T R}$ & $\overline{I C T}$ & & Subsample Incre & $g \operatorname{SINC}$ & GLE DISTR & $\overline{I C T}$ & \\
\hline Variable & Obs & Median & $\begin{array}{l}- \text { Binom. I } \\
\text { [95\% Conf }\end{array}$ & $\begin{array}{l}\text { Interp. -- } \\
\text { f. Interval] }\end{array}$ & Variable & Obs & Median & $\begin{array}{l}\text {-- Binom. } \\
{[95 \% \text { Con }}\end{array}$ & $\begin{array}{l}\text { Interp. -- } \\
\text { f. Interval] }\end{array}$ \\
\hline Ethnic(t-10) & 42 & 0.413317 & .3798746 & .4660986 & Ethnic(t-10) & 61 & 0.41117 & .3318195 & .442139 \\
\hline Ethnic(t) & 46 & 0.448415 & .4033347 & .4838997 & Ethnic(t) & 67 & 0.447307 & .4036738 & .4723136 \\
\hline Frac. Black(t-10) & 42 & 0.181325 & .1063943 & .2678239 & Frac. Black(t-10) & 61 & 0.172879 & .1219406 & .2654401 \\
\hline Frac. Black(t) & 46 & 0.214429 & .1339626 & .3017227 & Frac. Black(t) & 67 & 0.216827 & .1495089 & .2823543 \\
\hline Frac. Minrty(t-10) & 42 & 0.275677 & .2340786 & .3207284 & Frac. Minrty(t-10) & 61 & 0.275659 & .2040158 & .3016066 \\
\hline Frac. Minrty(t) & 46 & 0.323101 & .2709005 & .373635 & Frac. Minrty(t) & 67 & 0.322583 & .2719806 & .3521422 \\
\hline
\end{tabular}


Notes: time period $t$ for each variable refers to the final date of the period (for instance $t=2000$ for period 1990-2000). States fully covered under the 1975 renewal of the Voting Rights Act are Alabama, Georgia, Louisiana, Mississippi, South Carolina, Texas, and Virginia. Florida and North Carolina are only partially covered. Data exclude cities for which the change in electoral rule was dictated by court mandate or State law. 
Table VII

Size of Minority and City Electoral Rule: Within-city variation in States Fully Covered by Voting Rights Act

\begin{tabular}{|c|c|c|c|c|c|c|c|}
\hline Sample: & South & $\begin{array}{l}\text { South, } \\
\text { Cities, } \\
\text { Fully } \\
\text { covered } \\
\text { States }\end{array}$ & $\begin{array}{l}\text { South, } \\
\text { Cities, } \\
\text { Fully } \\
\text { covered } \\
\text { States, } \\
\text { pop }>2500\end{array}$ & $\begin{array}{l}\text { South, } \\
\text { Cities, } \\
\text { Fully } \\
\text { covered } \\
\text { States }\end{array}$ & $\begin{array}{l}\text { South, } \\
\text { Cities, } \\
\text { Fully } \\
\text { covered } \\
\text { States }\end{array}$ & $\begin{array}{l}\text { All U.S., } \\
\text { Fully } \\
\text { covered } \\
\text { States }\end{array}$ & $\begin{array}{l}\text { All U.S., } \\
\text { Fully } \\
\text { covered } \\
\text { States }\end{array}$ \\
\hline \multicolumn{8}{|c|}{$\begin{array}{l}\text { Panel (a): City Fixed Effects } \\
\text { ariable: Fraction of councilmen elected by district }\end{array}$} \\
\hline & (1) & (2) & $(3)$ & (4) & (5) & (6) & (7) \\
\hline Frac. Minority & $\begin{array}{l}-0.885 \\
{[0.308]^{\star \star \star}}\end{array}$ & $\begin{array}{l}-1.307 \\
{[0.393]^{\star \star \star}}\end{array}$ & $\begin{array}{l}-1.332 \\
{[0.404]^{\star \star \star}}\end{array}$ & $\begin{array}{l}-1.305 \\
{[0.393]^{\star \star *}}\end{array}$ & $\begin{array}{l}-0.85 \\
{[0.433]^{\star \star}}\end{array}$ & $\begin{array}{l}-1.27 \\
{[0.380]^{\star \star \star}}\end{array}$ & $\begin{array}{l}-0.849 \\
{[0.415]^{\star \star}}\end{array}$ \\
\hline$(\text { Frac. Minority })^{\wedge} 2$ & $\begin{array}{l}1.514 \\
{[0.475]^{\star \star \star}}\end{array}$ & $\begin{array}{l}1.781 \\
{[0.558]^{\star \star \star}}\end{array}$ & $\begin{array}{l}2.136 \\
{[0.608]^{\star \star \star}}\end{array}$ & $\begin{array}{l}1.79 \\
{[0.563]^{\star \star \star}}\end{array}$ & $\begin{array}{l}1.358 \\
{[0.584]^{\star *}}\end{array}$ & $\begin{array}{l}1.702 \\
{[0.525]^{\star \star \star}}\end{array}$ & $\begin{array}{l}1.305 \\
{[0.545]^{\star *}}\end{array}$ \\
\hline Log(City Population) & $\begin{array}{l}0.002 \\
{[0.038]}\end{array}$ & $\begin{array}{l}-0.007 \\
{[0.056]}\end{array}$ & $\begin{array}{l}0.013 \\
{[0.058]}\end{array}$ & $\begin{array}{l}-0.01 \\
{[0.060]}\end{array}$ & $\begin{array}{l}-0.034 \\
{[0.059]}\end{array}$ & $\begin{array}{l}-0.011 \\
{[0.051]}\end{array}$ & $\begin{array}{l}-0.022 \\
{[0.054]}\end{array}$ \\
\hline Log(Median Income) & & & & $\begin{array}{l}0.018 \\
{[0.139]}\end{array}$ & $\begin{array}{l}0.043 \\
{[0.146]}\end{array}$ & & $\begin{array}{l}0.022 \\
{[0.137]}\end{array}$ \\
\hline State trend & & & & & Included & & Included \\
\hline Observations & 4011 & 1992 & 1872 & 1991 & 1991 & 2171 & 2170 \\
\hline Number of cities & 1914 & 962 & 901 & 962 & 962 & 1056 & 1056 \\
\hline R-squared & 0.71 & 0.72 & 0.71 & 0.72 & 0.74 & 0.72 & 0.75 \\
\hline \multicolumn{8}{|c|}{$\begin{array}{l}\text { Panel (b): Arellano-Bond GMM } \\
\text { variable: Fraction of councilmen elec }\end{array}$} \\
\hline & (1) & $(2)$ & (3) & & & & \\
\hline Lag Single District & $\begin{array}{l}0.313 \\
{[0.056]^{\star \star \star}}\end{array}$ & $\begin{array}{l}0.293 \\
{[0.082]^{\star \star \star}}\end{array}$ & $\begin{array}{l}0.276 \\
{[0.079]^{\star \star \star}}\end{array}$ & & & & \\
\hline Frac. Minority & $\begin{array}{l}-1.644 \\
{[0.712]^{\star \star}}\end{array}$ & $\begin{array}{l}-2.326 \\
{[0.831]^{\star \star \star}}\end{array}$ & $\begin{array}{l}-2.389 \\
{[0.802]^{\star \star \star}}\end{array}$ & & & & \\
\hline$(\text { Frac. Minority })^{\wedge} 2$ & $\begin{array}{l}2.649 \\
{[1.002]^{\star \star \star}}\end{array}$ & $\begin{array}{l}2.66 \\
{[1.053]^{\star \star}}\end{array}$ & $\begin{array}{l}2.683 \\
{[0.983]^{\star \star \star}}\end{array}$ & & & & \\
\hline Log(City Population) & $\begin{array}{l}-0.342 \\
{[0.258]}\end{array}$ & $\begin{array}{l}-0.182 \\
{[0.282]}\end{array}$ & $\begin{array}{l}-0.163 \\
{[0.282]}\end{array}$ & & & & \\
\hline Second Order Serial & & & & & & & \\
\hline $\begin{array}{l}\text { Correlation } p \text {-value } \\
\mathrm{J} \text { test } p \text {-value }\end{array}$ & $\begin{array}{l}0.140 \\
0.123\end{array}$ & $\begin{array}{l}0.04 \\
0.172\end{array}$ & $\begin{array}{l}0.046 \\
0.142\end{array}$ & & & & \\
\hline Observations & 1506 & 768 & 758 & & & & \\
\hline Number of cities & 797 & 399 & 391 & & & & \\
\hline
\end{tabular}

Notes: Standard errors in brackets below coefficients. * significant at 10\%; ${ }^{\star \star}$ significant at 5\%; ;* significant at 1\%. In panel (a) standard errors are clustered at the city level. All regressions include year fixed effects. Both Panel (a) and (b) refer to period 1970-2000. States fully covered under the 1975 renewal of the Voting Rights Act are Alabama, Georgia, Louisiana, Mississippi, South Carolina, Texas, and Virginia. 
Table VIII

Size of Minority and City Form of Government: Within-city variation

\begin{tabular}{|c|c|c|c|c|c|c|}
\hline Estimator: & $\begin{array}{l}\text { Fixed } \\
\text { Effects }\end{array}$ & $\begin{array}{l}\text { Fixed } \\
\text { Effects } \\
\text { South, } \\
\text { Cities > } \\
2500\end{array}$ & $\begin{array}{l}\text { Fixed } \\
\text { Effects }\end{array}$ & $\begin{array}{l}\text { Fixed } \\
\text { Effects }\end{array}$ & $\begin{array}{l}\text { Fixed } \\
\text { Effects }\end{array}$ & $\begin{array}{l}\text { Fixed } \\
\text { Effects }\end{array}$ \\
\hline \multicolumn{7}{|c|}{$\begin{array}{l}\text { Panel (a): Post } 1967 \\
\text { variable: Form of govern }\end{array}$} \\
\hline & (1) & (2) & (3) & (4) & (5) & (6) \\
\hline Frac. Minority & $\begin{array}{l}-0.428 \\
{[0.347]}\end{array}$ & $\begin{array}{l}-0.405 \\
{[0.367]}\end{array}$ & $\begin{array}{l}-0.458 \\
{[0.348]}\end{array}$ & $\begin{array}{l}-0.236 \\
{[0.388]}\end{array}$ & $\begin{array}{l}-0.211 \\
{[0.244]}\end{array}$ & $\begin{array}{l}-0.143 \\
{[0.258]}\end{array}$ \\
\hline$($ Frac. Minority)^2 & $\begin{array}{l}0.699 \\
{[0.515]}\end{array}$ & $\begin{array}{l}0.748 \\
{[0.587]}\end{array}$ & $\begin{array}{l}0.658 \\
{[0.511]}\end{array}$ & $\begin{array}{l}0.375 \\
{[0.535]}\end{array}$ & $\begin{array}{l}0.459 \\
{[0.325]}\end{array}$ & $\begin{array}{l}0.295 \\
{[0.322]}\end{array}$ \\
\hline Log(City Population) & $\begin{array}{l}0.055 \\
{[0.048]}\end{array}$ & $\begin{array}{l}0.067 \\
{[0.057]}\end{array}$ & $\begin{array}{l}0.077 \\
{[0.051]}\end{array}$ & $\begin{array}{l}0.078 \\
{[0.050]}\end{array}$ & $\begin{array}{l}0.036 \\
{[0.037]}\end{array}$ & $\begin{array}{l}0.047 \\
{[0.036]}\end{array}$ \\
\hline Log(Median Income) & & & $\begin{array}{l}-0.141 \\
{[0.088]}\end{array}$ & $\begin{array}{l}-0.135 \\
{[0.091]}\end{array}$ & & $\begin{array}{l}-0.135 \\
{[0.065]^{\star \star}}\end{array}$ \\
\hline State trend & & & & Included & & Included \\
\hline Observations & 4492 & 4161 & 4491 & 4491 & 14082 & 14081 \\
\hline Number of cities & 1980 & 1812 & 1980 & 1980 & 6827 & 6827 \\
\hline R-squared & 0.79 & 0.79 & 0.79 & 0.8 & 0.86 & 0.86 \\
\hline \multicolumn{7}{|c|}{ Panel (b): Pre 1967} \\
\hline & $(1)$ & $(2)$ & (3) & (4) & & \\
\hline Frac. Minority & $\begin{array}{l}0.091 \\
{[0.650]}\end{array}$ & $\begin{array}{l}0.387 \\
{[0.970]}\end{array}$ & $\begin{array}{l}-0.481 \\
{[1.143]}\end{array}$ & $\begin{array}{l}-0.455 \\
{[1.194]}\end{array}$ & & \\
\hline$(\text { Frac. Minority })^{\wedge} 2$ & $\begin{array}{l}0.378 \\
{[0.815]}\end{array}$ & $\begin{array}{l}-0.175 \\
{[1.648]}\end{array}$ & $\begin{array}{l}0.742 \\
{[1.782]}\end{array}$ & $\begin{array}{l}0.687 \\
{[1.873]}\end{array}$ & & \\
\hline Log(City Population) & $\begin{array}{l}0.018 \\
{[0.066]}\end{array}$ & $\begin{array}{l}0.017 \\
{[0.066]}\end{array}$ & $\begin{array}{l}0.059 \\
{[0.061]}\end{array}$ & $\begin{array}{l}0.046 \\
{[0.065]}\end{array}$ & & \\
\hline Log(Median Income) & & & $\begin{array}{l}-0.226 \\
{[0.082]^{\star \star \star}}\end{array}$ & $\begin{array}{l}-0.188 \\
{[0.085]^{\star \star}}\end{array}$ & & \\
\hline State trend & & & & Included & & \\
\hline Observations & 2454 & 2447 & 2087 & 2087 & & \\
\hline Number of cities & 979 & 974 & 978 & 978 & & \\
\hline R-squared & 0.77 & 0.77 & 0.82 & 0.83 & & \\
\hline
\end{tabular}

Notes: Corrected standard errors in brackets below coefficients. * significant at 10\%; ${ }^{\star \star}$ significant at $5 \%$; ${ }^{* *}$ significant at $1 \%$. In panels (a) and (b) standard errors are clustered at the city level. All regressions include year fixed effects. Panel (a) covers the period 19702000. Panel (b) covers the period 1930-1970. 
Table IX

Size of Minority and City Form of Government: Within. city variation

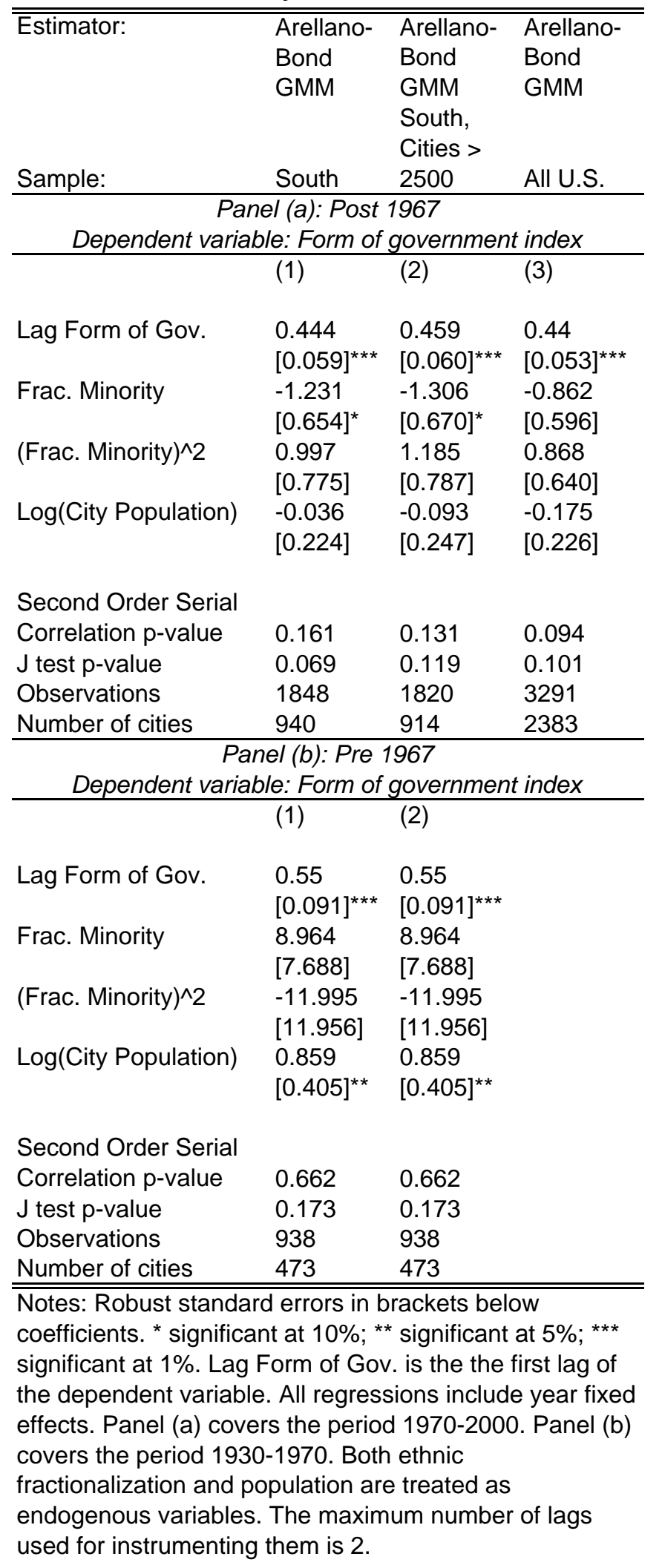


Table X

Size of Minority and Form of Government Indexes: Within-city variation

\begin{tabular}{|c|c|c|c|c|c|c|c|c|}
\hline Estimator: & $\begin{array}{l}\text { Fixed } \\
\text { Effects }\end{array}$ & $\begin{array}{l}\text { Fixed } \\
\text { Effects }\end{array}$ & $\begin{array}{l}\text { Fixed } \\
\text { Effects }\end{array}$ & $\begin{array}{l}\text { Fixed } \\
\text { Effects } \\
\text { South, } \\
\text { Cities > } \\
2500 \\
\end{array}$ & $\begin{array}{l}\text { Fixed } \\
\text { Effects }\end{array}$ & $\begin{array}{l}\text { Fixed } \\
\text { Effects }\end{array}$ & $\begin{array}{l}\text { Fixed } \\
\text { Effects }\end{array}$ & $\begin{array}{l}\text { Fixed } \\
\text { Effects } \\
\text { All U.S., } \\
\text { Cities> } \\
2500 \\
\end{array}$ \\
\hline \multicolumn{9}{|c|}{ Period 1980-2000 } \\
\hline $\begin{array}{l}\text { Dependent } \\
\text { variable: }\end{array}$ & $\begin{array}{l}\text { Term limit } \\
\text { for Mayor }\end{array}$ & $\begin{array}{l}\text { Length } \\
\text { term of } \\
\text { Mayor }\end{array}$ & $\begin{array}{l}\text { Executive } \\
\text { Index }\end{array}$ & $\begin{array}{l}\text { Executive } \\
\text { Index }\end{array}$ & $\begin{array}{l}\text { Executive } \\
\text { Index }\end{array}$ & $\begin{array}{l}\text { Executive } \\
\text { Index }\end{array}$ & $\begin{array}{l}\text { Executive } \\
\text { Index }\end{array}$ & $\begin{array}{l}\text { Executive } \\
\text { Index }\end{array}$ \\
\hline & (1) & (2) & (3) & (4) & (5) & (6) & $(7)$ & (8) \\
\hline Frac. Minority & $\begin{array}{l}0.281 \\
{[0.154]^{*}}\end{array}$ & $\begin{array}{l}0.138 \\
{[0.517]}\end{array}$ & $\begin{array}{l}-0.908 \\
{[1.610]}\end{array}$ & $\begin{array}{l}-0.413 \\
{[1.596]}\end{array}$ & $\begin{array}{l}-0.927 \\
{[1.635]}\end{array}$ & $\begin{array}{l}-0.074 \\
{[1.682]}\end{array}$ & $\begin{array}{l}0.811 \\
{[0.954]}\end{array}$ & $\begin{array}{l}0.879 \\
{[0.982]}\end{array}$ \\
\hline$(\text { Frac. Minority })^{\wedge} 2$ & $\begin{array}{l}-0.375 \\
{[0.185]^{\star \star}}\end{array}$ & $\begin{array}{l}0.345 \\
{[0.700]}\end{array}$ & $\begin{array}{l}1.137 \\
{[2.268]}\end{array}$ & $\begin{array}{l}0.247 \\
{[2.235]}\end{array}$ & $\begin{array}{l}1.144 \\
{[2.270]}\end{array}$ & $\begin{array}{l}0.577 \\
{[2.424]}\end{array}$ & $\begin{array}{l}-0.36 \\
{[1.260]}\end{array}$ & $\begin{array}{l}-0.452 \\
{[1.280]}\end{array}$ \\
\hline \multicolumn{9}{|l|}{ Log(City } \\
\hline Population) & $\begin{array}{l}0.033 \\
{[0.024]}\end{array}$ & $\begin{array}{l}0.068 \\
{[0.061]}\end{array}$ & $\begin{array}{l}0.089 \\
{[0.149]}\end{array}$ & $\begin{array}{l}-0.004 \\
{[0.169]}\end{array}$ & $\begin{array}{l}0.093 \\
{[0.161]}\end{array}$ & $\begin{array}{l}0.003 \\
{[0.189]}\end{array}$ & $\begin{array}{l}0.054 \\
{[0.087]}\end{array}$ & $\begin{array}{l}0.013 \\
{[0.111]}\end{array}$ \\
\hline Log(Median & & & & & & & & \\
\hline $\begin{array}{l}\text { Income) } \\
\text { State trend }\end{array}$ & & & & & $\begin{array}{l}-0.027 \\
{[0.393]}\end{array}$ & $\begin{array}{l}0.065 \\
{[0.434]} \\
\text { Included }\end{array}$ & & $\begin{array}{l}0.2 \\
{[0.240]}\end{array}$ \\
\hline Observations & 3488 & 4423 & 2754 & 2504 & 2754 & 2754 & 9488 & 8731 \\
\hline Number of cities & 1723 & 1970 & 1547 & 1391 & 1547 & 1547 & 5474 & 4989 \\
\hline R-squared & 0.77 & 0.86 & 0.89 & 0.9 & 0.89 & 0.89 & 0.88 & 0.88 \\
\hline
\end{tabular}

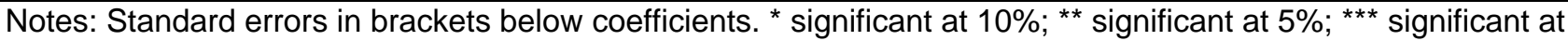
1\%. Standard errors are clustered at the city level. All regressions include year fixed effects. Term limit of mayor is computed as 1-max no. terms/8 if term limits are present, 0 otherwise. The executive index is computed as the sum of 1 if the system is mayor-council, 1 if the mayor has veto power, and lenght of term for the mayor divided by 7 , and subtracting term limit, - 1 for the presence of recall, initiative or popular referendum. 
Table DI

Summary Statistics (All U.S. sample, excl. South) Summary Statistics (All U.S. sample, incl. South)

\begin{tabular}{|c|c|c|c|c|c|c|c|c|c|c|c|c|c|}
\hline year & & $\begin{array}{l}\text { Single } \\
\text { District }\end{array}$ & $\begin{array}{l}\text { Form of } \\
\text { Governme } \\
\text { nt }\end{array}$ & $\begin{array}{l}\text { Fract. } \\
\text { Minority }\end{array}$ & Population & \begin{tabular}{l|} 
Median \\
Household \\
Income
\end{tabular} & year & & $\begin{array}{l}\text { Single } \\
\text { District }\end{array}$ & $\begin{array}{l}\text { Form of } \\
\text { Governme } \\
\text { nt }\end{array}$ & $\begin{array}{l}\text { Fract. } \\
\text { Minority }\end{array}$ & Population & $\begin{array}{l}\text { Median } \\
\text { Household } \\
\text { Income }\end{array}$ \\
\hline \multirow[t]{5}{*}{1980} & mean & 0.264445 & 0.366814 & 0.067241 & 22787.53 & 22809.2 & \multirow[t]{5}{*}{1980} & mean & 0.23934 & 0.377363 & 0.09799 & 22559.6 & 21573.12 \\
\hline & st. dev. & 0.408385 & 0.683129 & 0.111262 & 142177.4 & 8163.656 & & st. dev. & 0.395861 & 0.647312 & 0.137489 & 127573.8 & 7987.236 \\
\hline & $\mathrm{min}$. & 0 & -1 & 0 & 161 & 8347.087 & & min. & 0 & -1 & 0 & 113 & 6479.371 \\
\hline & $\max$ & 1 & 1 & 0.95962 & 7071638 & 91020.62 & & $\max$ & 1 & 1 & 0.998817 & 7071638 & 91020.62 \\
\hline & N. obs. & 2870 & 3176 & 3151 & 3176 & 3176 & & N. obs. & 3943 & 4338 & 4297 & 4338 & 4338 \\
\hline \multirow[t]{5}{*}{1990} & mean & 0.221614 & 0.352992 & 0.085131 & 20925.98 & 25754.26 & \multirow[t]{5}{*}{1990} & mean & 0.22391 & 0.3656 & 0.118933 & 20816.74 & 23949.99 \\
\hline & st. dev. & 0.381637 & 0.662213 & 0.129206 & 75066.69 & 11934.09 & & st. dev. & 0.382196 & 0.625077 & 0.153624 & 69684.18 & 11484.99 \\
\hline & $\min$. & 0 & -1 & 0 & 107 & 6783.474 & & $\min$. & 0 & -1 & 0 & 107 & 5696.253 \\
\hline & $\max$ & 1 & 1 & 0.994365 & 3485398 & 114767.4 & & $\max$. & 1 & 1 & 0.994365 & 3485398 & 114767.4 \\
\hline & N. obs. & 2904 & 3476 & 3455 & 3476 & 3476 & & N. obs. & 3976 & 4814 & 4754 & 4814 & 4814 \\
\hline \multirow[t]{5}{*}{2000} & mean & 0.275712 & 0.278485 & 0.125633 & 22625.3 & 27690.47 & \multirow[t]{5}{*}{2000} & mean & 0.287567 & 0.290456 & 0.158393 & 23113.37 & 26127.72 \\
\hline & st. dev. & 0.407991 & 0.660554 & 0.153197 & 83089.34 & 12362.81 & & st. dev. & 0.412552 & 0.623114 & 0.171226 & 84880.19 & 12285.1 \\
\hline & $\min$. & 0 & -1 & 0 & 124 & 8470.961 & & $\min$. & 0 & -1 & 0 & 124 & 8309.526 \\
\hline & $\max$. & 1 & 1 & 0.979246 & 3694834 & 116144.6 & & $\max$. & 1 & 1 & 0.993369 & 3694834 & 116144.6 \\
\hline & N. obs. & 2671 & 2984 & 2984 & 2984 & 2984 & & N. obs. & 3681 & 4097 & 4097 & 4097 & 4097 \\
\hline \multirow[t]{5}{*}{ Total } & mean & 0.25328 & 0.334475 & 0.091855 & 22065.77 & 25383.17 & \multirow[t]{5}{*}{ Total } & mean & 0.249355 & 0.346215 & 0.124384 & 22097.58 & 23845.18 \\
\hline & st. dev. & 0.399898 & 0.669677 & 0.133983 & 104075.6 & 11159.28 & & st. dev. & 0.397537 & 0.632916 & 0.15634 & 96543.37 & 10898.35 \\
\hline & $\min$. & 0 & -1 & 0 & 107 & 6783.474 & & $\min$. & 0 & -1 & 0 & 107 & 5696.253 \\
\hline & $\max$ & 1 & 1 & 0.994365 & 7071638 & 116144.6 & & $\max$. & 1 & 1 & 0.998817 & 7071638 & 116144.6 \\
\hline & N. obs. & 8445 & 9636 & 9590 & 9636 & 9636 & & N. obs. & 11600 & 13249 & 13148 & 13249 & 13249 \\
\hline
\end{tabular}


Table DII

Summary Statistics (South sample)

\begin{tabular}{|c|c|c|c|c|c|}
\hline & & \multicolumn{4}{|c|}{ South Region } \\
\hline \multicolumn{2}{|l|}{ year } & \begin{tabular}{|l|} 
Single \\
District
\end{tabular} & $\begin{array}{l}\text { Form of } \\
\text { Governme } \\
\text { nt }\end{array}$ & $\begin{array}{l}\text { Fract. } \\
\text { Minority }\end{array}$ & Population \\
\hline \multirow[t]{5}{*}{1930} & mean & 0.190187 & 0.614458 & 0.240152 & 55689.73 \\
\hline & st. dev. & 0.341789 & 0.67566 & 0.152765 & 97710.1 \\
\hline & $\min$. & 0 & -1 & 0.00094 & 284.928 \\
\hline & $\max$ & 0.947368 & 1 & 0.96162 & 804874.1 \\
\hline & N. obs. & 144 & 166 & 137 & 137 \\
\hline \multirow[t]{5}{*}{1940} & mean & 0.367765 & 0.231325 & 0.221453 & 44127.13 \\
\hline & st. dev. & 0.459492 & 0.795204 & 0.145513 & 85805.16 \\
\hline & $\min$. & 0 & -1 & 0.000239 & 4868 \\
\hline & $\max$ & 1 & 1 & 0.597693 & 859100.3 \\
\hline & N. obs. & 415 & 415 & 229 & 229 \\
\hline \multirow[t]{5}{*}{1950} & mean & 0.345231 & 0.254065 & 0.208854 & 32005.15 \\
\hline & st. dev. & 0.452349 & 0.74599 & 0.144826 & 73305.76 \\
\hline & $\min$. & 0 & -1 & 0.000111 & 2774 \\
\hline & $\max$ & 1 & 1 & 0.723511 & 949708.4 \\
\hline & N. obs. & 486 & 492 & 492 & 492 \\
\hline \multirow[t]{5}{*}{1960} & mean & 0.253952 & 0.264264 & 0.194137 & 34242.28 \\
\hline & st. dev. & 0.41375 & 0.675556 & 0.145493 & 82867.91 \\
\hline & $\min$. & 0 & -1 & 0 & 3202.001 \\
\hline & $\max$ & 1 & 1 & 0.694678 & 939023.6 \\
\hline & N. obs. & 656 & 666 & 663 & 663 \\
\hline \multirow[t]{5}{*}{1970} & mean & 0.161332 & 0.283726 & 0.17797 & 29274.97 \\
\hline & st. dev. & 0.354326 & 0.555411 & 0.150278 & 79091.1 \\
\hline & $\min$. & 0 & -1 & 0 & 2406 \\
\hline & max. & 1 & 1 & 0.770336 & 1199388 \\
\hline & N. obs. & 904 & 934 & 936 & 936 \\
\hline \multirow[t]{5}{*}{1980} & mean & 0.17219 & 0.406196 & 0.182536 & 21936.64 \\
\hline & st. dev. & 0.351701 & 0.536582 & 0.164655 & 74266.77 \\
\hline & $\min$. & 0 & -1 & 0 & 113 \\
\hline & $\max$ & 1 & 1 & 0.998817 & 1595138 \\
\hline & N. obs. & 1073 & 1162 & 1146 & 1162 \\
\hline \multirow[t]{5}{*}{1990} & mean & 0.23013 & 0.398356 & 0.208838 & 20532.95 \\
\hline & st. dev. & 0.383814 & 0.515051 & 0.175684 & 53238.92 \\
\hline & $\min$. & 0 & -1 & 0 & 243 \\
\hline & $\max$ & 1 & 1 & 0.986468 & 935926.6 \\
\hline & N. obs. & 1072 & 1338 & 1299 & 1338 \\
\hline \multirow[t]{5}{*}{2000} & mean & 0.318919 & 0.322552 & 0.246224 & 24421.92 \\
\hline & st. dev. & 0.422985 & 0.50821 & 0.185563 & 89530.48 \\
\hline & $\min$. & 0 & -1 & 0 & 138 \\
\hline & $\max$ & 1 & 1 & 0.993369 & 1954847 \\
\hline & N. obs. & 1010 & 1113 & 1113 & 1113 \\
\hline \multirow[t]{5}{*}{ Total } & mean & 0.24545 & 0.33853 & 0.205515 & 26973.67 \\
\hline & st. dev. & 0.401669 & 0.593737 & 0.166296 & 76418.88 \\
\hline & $\min$. & 0 & -1 & 0 & 113 \\
\hline & $\max$ & 1 & 1 & 0.998817 & 1954847 \\
\hline & N. obs. & 5760 & 6286 & 6015 & 6070 \\
\hline
\end{tabular}




\section{States Covered as a Whole:}

\begin{tabular}{|c|c|c|}
\hline Alabama & Nov. 1, 196430 FR 9897 & Aug. 7, 1965. \\
\hline Alaska & Nov. 1, 197240 FR 49422 & Oct. $22,1975$. \\
\hline Arizona & Nov. 1, 197240 FR 43746 & Sept. 23, 1975. \\
\hline Georgia & Nov. 1, 196430 FR 9897 & Aug. 7, 1965. \\
\hline Louisiana & Nov. 1, 196430 FR 9897 & Aug. 7, 1965. \\
\hline Mississippi & Nov. 1, 196430 FR 9897 & Aug. 7, 1965. \\
\hline South Carolina & Nov. 1, 196430 FR 9897 & Aug. 7, 1965. \\
\hline Texas & Nov. 1, 197240 FR 43746 & Sept. 23, 1975. \\
\hline Virginia & Nov. 1, 196430 FR 9897 & Aug. 7, 1965. \\
\hline
\end{tabular}

\section{Covered Counties in States Not Covered as a Whole:}

California:

$\begin{array}{llll}\text { Kings County } & \text { Nov. 1, 1972 } & \text { 40 FR 43746 } & \text { Sept. 23. } 1975 . \\ \text { Merced County } & \text { Nov. 1, 1972 } & \text { 40 FR 43746 } & \text { Sept. 23, 1975. } \\ \text { Monterey County } & \text { Nov. 1, 1968 } & \text { 36 FR 5809 } & \text { Mar. 27, 1971. } \\ \text { Yuba County } & \text { Nov. 1, 1968 } & \text { 36 FR 5809 } & \text { Mar. 27, 1971. } \\ \text { Yuba County } & \text { Nov. 1, 1972 } & \text { 41 FR 784 } & \text { Jan. 5, 1976. }\end{array}$

Florida:

Collier County

Hardee County

Hendry County

Nov. 1, 1972

Nov. 1, 1972

Nov. 1, 1972

41 FR 34329

40 FR 43746

41 FR 34329

40 FR 43746

Hillsborough County

Monroe County

Nov. 1, 1972

New York:

Bronx County

Bronx County

Kings County

Kings County

New York County

North Carolina:

Anson County

Beaufort County

Bertie County

Bladen County

Camden County

Caswell County

Chowan County

Cleveland County

Craven County

Nov. 1, 1968

Nov. 1, 1972

Nov. 1, 1968

Nov. 1, 1972

40 FR 43746

Nov. 1, 1968

36 FR 5809

40 FR 43746

36 FR 5809

40 FR 43746

36 FR 5809

Nov. 1, 196430 FR 9897

Nov. 1, 196431 FR 5081

Nov. 1, 1964 30 FR 9897

Nov. 1, 196431 FR 5081

Nov. 1, 196431 FR 3317

Nov. 1, 1964 30 FR 9897

Nov. 1, 1964 30 FR 9897

Nov. 1, 196431 FR 5081

Nov. 1, 196430 FR 9897

Cumberland County
Nov. 1, 196430 FR 9897
Aug. 13, 1976.

Sept. 23, 1975.

Aug. 13, 1976.

Sept. 23, 1975.

Sept. 23, 1975.

Mar. 27, 1971.

Sept. 23, 1975.

Mar. 27, 1971.

Sept. 23, 1975.

Mar. 27, 1971.

Aug. 7, 1965.

Mar. 29, 1966.

Aug. 7, 1965.

Mar. 29, 1966.

Mar. 2, 1966.

Aug. 7, 1965.

Aug. 7, 1965.

Mar. 29, 1966.

Aug. 7, 1965.

Aug. 7, 1965. 


\begin{tabular}{|c|c|c|c|}
\hline Edgecombe County & Nov. 1, 1964 & 30 FR 9897 & Aug. 7, 1965. \\
\hline Franklin County & Nov. 1, 1964 & 30 FR 9897 & Aug. 7, 1965. \\
\hline Gaston County & Nov. 1, 1964 & 31 FR 5081 & Mar. 29, 1966. \\
\hline Gates County & Nov. 1, 1964 & 30 FR 9897 & Aug. 7, 1965. \\
\hline Granville County & Nov. 1, 1964 & 30 FR 9897 & Aug. 7, 1965. \\
\hline Greene County & Nov. 1, 1964 & 30 FR 9897 & Aug. 7, 1965. \\
\hline Guilford County & Nov. 1, 1964 & 31 FR 5081 & Mar. 29, 1966. \\
\hline Halifax County & Nov. 1, 1964 & 30 FR 9897 & Aug. 7, 1965. \\
\hline Harnett County & Nov. 1, 1964 & 31 FR 5081 & Mar. 29, 1966. \\
\hline Hertford County & Nov. 1, 1964 & 30 FR 9897 & Aug. 7, 1965. \\
\hline Hoke County & Nov. 1, 1964 & 30 FR 9897 & Aug. 7, 1965. \\
\hline Jackson County & Nov. 1, 1972 & 40 FR 49422 & Oct. $22,1975$. \\
\hline Lee County & Nov. 1, 1964 & 31 FR 5081 & Mar. 29, 1966. \\
\hline Lenoir County & Nov. 1, 1964 & 30 FR 9897 & Aug. 7, 1965. \\
\hline Martin County & Nov. 1, 1964 & 31 FR 19 & Jan. 4, 1966. \\
\hline Nash County & Nov. 1, 1964 & 30 FR 9897 & Aug. 7, 1965. \\
\hline Northampton County & Nov. 1, 1964 & 30 FR 9897 & Aug. 7, 1965. \\
\hline Onslow County & Nov. 1, 1964 & 30 FR 9897 & Aug. 7, 1965. \\
\hline Pasquotank County & Nov. 1, 1964 & 30 FR 9897 & Aug. 7, 1965. \\
\hline Perquimans County & Nov. 1, 1964 & 31 FR 3317 & Mar. 2, 1966. \\
\hline Person County & Nov. 1, 1964 & 30 FR 9897 & Aug. 7, 1965. \\
\hline Pitt County & Nov. 1, 1964 & 30 FR 9897 & Aug. 7, 1965. \\
\hline Robeson County & Nov. 1, 1964 & 30 FR 9897 & Aug. 7, 1965. \\
\hline Rockingham County & Nov. 1, 1964 & 31 FR 5081 & Mar. 29, 1966. \\
\hline Scotland County & Nov. 1, 1964 & 30 FR 9897 & Aug. 7, 1965. \\
\hline Union County & Nov. 1, 1964 & 31 FR 5081 & Mar. 29, 1966. \\
\hline Vance County & Nov. 1, 1964 & 30 FR 9897 & Aug. 7, 1965. \\
\hline Washington County & Nov. 1, 1964 & 31 FR 19 & Jan. 4, 1966. \\
\hline Wayne County & Nov. 1, 1964 & 30 FR 9897 & Aug. 7, 1965. \\
\hline Wilson County & Nov. 1, 1964 & 30 FR 9897 & Aug. 7, 1965. \\
\hline \multicolumn{4}{|l|}{ South Dakota: } \\
\hline Shannon County & Nov. 1, 1972 & 41 FR 784 & Jan. 5, 1976. \\
\hline Todd County & Nov. 1, 1972 & 41 FR 784 & Jan. 5, 1976. \\
\hline
\end{tabular}

\section{Covered Townships in States Not Covered as a Whole}

Michigan:

Allegan County: Clyde Township Nov. 1, 1972 41 FR 34329 Aug. 13, 1976.

Saginaw County: Buena Vista Township Nov. 1, 197241 FR 34329 Aug. 13, 1976.

New Hampshire:

Cheshire County: $\quad$ Rindge Town Nov. 1, 1968 39 FR 16912 May 10, 1974.

Coos County: Millsfield Township Nov. 1, 1968 39 FR 16912 May 10, 1974.

Pinkhams Grant Nov. 1, 1968 39 FR 16912 May 10, 1974.

Stewartstown Town Nov. 1, 1968 39 FR 16912 May 10, 1974.

Stratford Town Nov. 1, 1968 39 FR 16912 May 10, 1974. 
Grafton County: $\quad$ Benton Town Nov. 1, 1968 39 FR 16912 May 10, 1974. Hillsborough County: Antrim Town Nov. 1, 196839 FR 16912 May 10, 1974. Merrimack County: Boscawen Town Nov. 1, 196839 FR 16912 May 10, 1974. Rockingham County: Newington Town Nov. 1, 196839 FR 16912 May 10, 1974.

Sullivan County: Unity Town Nov. 1, 1968 39 FR 16912 May 10, 1974.

Source: Department of Justice. 
Table A I: Sample Selection (years 1980-2000)

\begin{tabular}{|c|c|c|c|c|c|c|c|c|c|c|}
\hline \multirow[b]{2}{*}{ year } & & \multicolumn{3}{|c|}{ All Census Places and selected MCD's } & \multicolumn{3}{|c|}{$\begin{array}{c}\text { Census Places and selected MCD's Not } \\
\text { in ICMA Sample }\end{array}$} & \multicolumn{3}{|c|}{$\begin{array}{l}\text { ICMA Form of Government Sample } \\
\text { (ICMA Survey Respondents) }\end{array}$} \\
\hline & & Ethnic Frac. & Population & Med. Income & Ethnic Frac. & Population & Med. Income & Ethnic Frac. & Population & Med. Income \\
\hline \multirow[t]{5}{*}{1980} & mean & 0.119897 & 9118.068 & 19208.98 & 0.1160492 & 7172.804 & 18883.43 & 0.1467891 & 22713.42 & 21484.27 \\
\hline & st. dev. & 0.1455027 & 63175.11 & 6744.721 & 0.14351 & 47311.46 & 6485.699 & 0.1561237 & 126620.4 & 7971.08 \\
\hline & $\min$. & & 100 & 3032.767 & 0 & 100 & 3032.767 & 0 & 113 & 6479.369 \\
\hline & $\max$. & 0.664348 & 7071639 & 91020.63 & 0.664348 & 3122307 & 91020.63 & 0.6593081 & 7071639 & 91020.63 \\
\hline & N. obs. & 35439 & 35439 & 35439 & 31003 & 31003 & 31003 & 4436 & 4436 & 4436 \\
\hline \multirow[t]{5}{*}{1990} & mean & 0.1006002 & 6170.385 & 20617.8 & 0.0919233 & 4444.582 & 20215.08 & 0.1712403 & 20220.49 & 23896.39 \\
\hline & st. dev. & 0.1471291 & 50790.99 & 8899.342 & 0.1423105 & 48046.86 & 8439.477 & 0.1655406 & 67579.89 & 11492.09 \\
\hline & $\min$. & & 100 & 3824.79 & 0 & 100 & 3824.79 & 0 & 107 & 5696.251 \\
\hline & $\max$. & 0.6645895 & 7322564 & 114767.4 & 0.6645895 & 7322564 & 114767.4 & 0.6546158 & 3485398 & 114767.4 \\
\hline & N. obs. & 44929 & 44929 & 44929 & 40014 & 40014 & 40014 & 4915 & 4915 & 4915 \\
\hline \multirow[t]{5}{*}{2000} & mean & 0.1501133 & 8582.013 & 22822.19 & 0.1439961 & 7315.146 & 22528.88 & 0.219 & 81.33 & 26156 \\
\hline & st. dev. & 0.1628525 & 62828.02 & 9093.845 & 0.1607504 & 60455.36 & 8684.614 & 0.1702933 & 83952.82 & 12382.84 \\
\hline & $\min$. & & 100 & 2177.7 & 0 & 100 & 2177.7 & 0 & 124 & 8309.523 \\
\hline & $\max$. & 0.6665496 & 8008278 & 116144.6 & 0.6665496 & 8008278 & 116144.6 & 0.6632373 & 3694834 & 116144.6 \\
\hline & N. obs. & 51851 & 51851 & 51851 & 47658 & 47658 & 47658 & 4193 & 4193 & 4193 \\
\hline \multirow[t]{5}{*}{ Total } & mean & 0.1251894 & 7906.204 & 21104.66 & 0.1191376 & 6310.084 & 20796.38 & 0.1782162 & 21891.7 & 23805.9 \\
\hline & st. dev. & 0.1545542 & 59126.08 & 8586.952 & 0.151941 & 53222 & 8219.904 & 0.166656 & 95344.94 & 10939.28 \\
\hline & $\min$ & & 100 & 2177.7 & 0 & 100 & 2177.7 & 0 & 107 & 5696.251 \\
\hline & $\max$ & 0.6665496 & 8008278 & 116144.6 & 0.6665496 & 8008278 & 116144.6 & 0.6632373 & 7071639 & 116144.6 \\
\hline & N. obs. & 132219 & 132219 & 132219 & 118675 & 118675 & 118675 & 13544 & 13544 & 13544 \\
\hline
\end{tabular}

Note: Median income equal to 0 indicates a value of income zeroed by the U.S. Census for confidentiality purposes. Only 2 municipalities in 1980 and 2 in 2000 required such treatment and were dropped from the sample. 11185 municipalities below 100 inhabitants were dropped and 4 obs. with inconsistent racial data were dropped.

Table A Il: Response Selection (year 2000)

\begin{tabular}{|c|c|c|c|c|}
\hline \multirow{7}{*}{$\frac{\text { year }}{2000}$} & & \multirow{2}{*}{\multicolumn{3}{|c|}{$\begin{array}{l}\text { ICMA Form of Government Full Sample } \\
\text { Ethnic Frac. Population Med. Income }\end{array}$}} \\
\hline & & & & \\
\hline & mean & 0.2208746 & 22780.94 & 25502.09 \\
\hline & st. dev. & 0.1740321 & 121694.4 & 12237.76 \\
\hline & $\min$ & 0 & 124 & 5897.793 \\
\hline & $\max$ & 0.6658266 & 8008278 & 116144.6 \\
\hline & N. obs. & 7757 & 7757 & 7757 \\
\hline \multirow{6}{*}{2000} & & \multicolumn{3}{|c|}{ ICMA Survey Respondents } \\
\hline & mean & 0.2196418 & 22981.33 & 26156 \\
\hline & st. dev. & 0.1702933 & 83952.82 & 12382.84 \\
\hline & $\min$ & 0 & 124 & 8309.523 \\
\hline & $\max$ & 0.6632373 & 3694834 & 116144.6 \\
\hline & N. obs. & 4193 & 4193 & 4193 \\
\hline \multirow{6}{*}{2000} & & \multicolumn{3}{|c|}{ ICMA Survey Non Respondents } \\
\hline & mean & 0.2223249 & 22545.18 & 24732.77 \\
\hline & st. dev. & 0.1783436 & 154742.4 & 12021.1 \\
\hline & $\min$ & 0 & 124 & 5897.793 \\
\hline & $\max$ & 0.6658266 & 8008278 & 116144.6 \\
\hline & N. obs. & 3564 & 3564 & 3564 \\
\hline
\end{tabular}

Note: the ICMA 2001 FOG survey sample universe has been provided by ICMA. We thank Sebia Clark for making the data available to us. 
Table A III: Sample Selection (years 1930-1970)

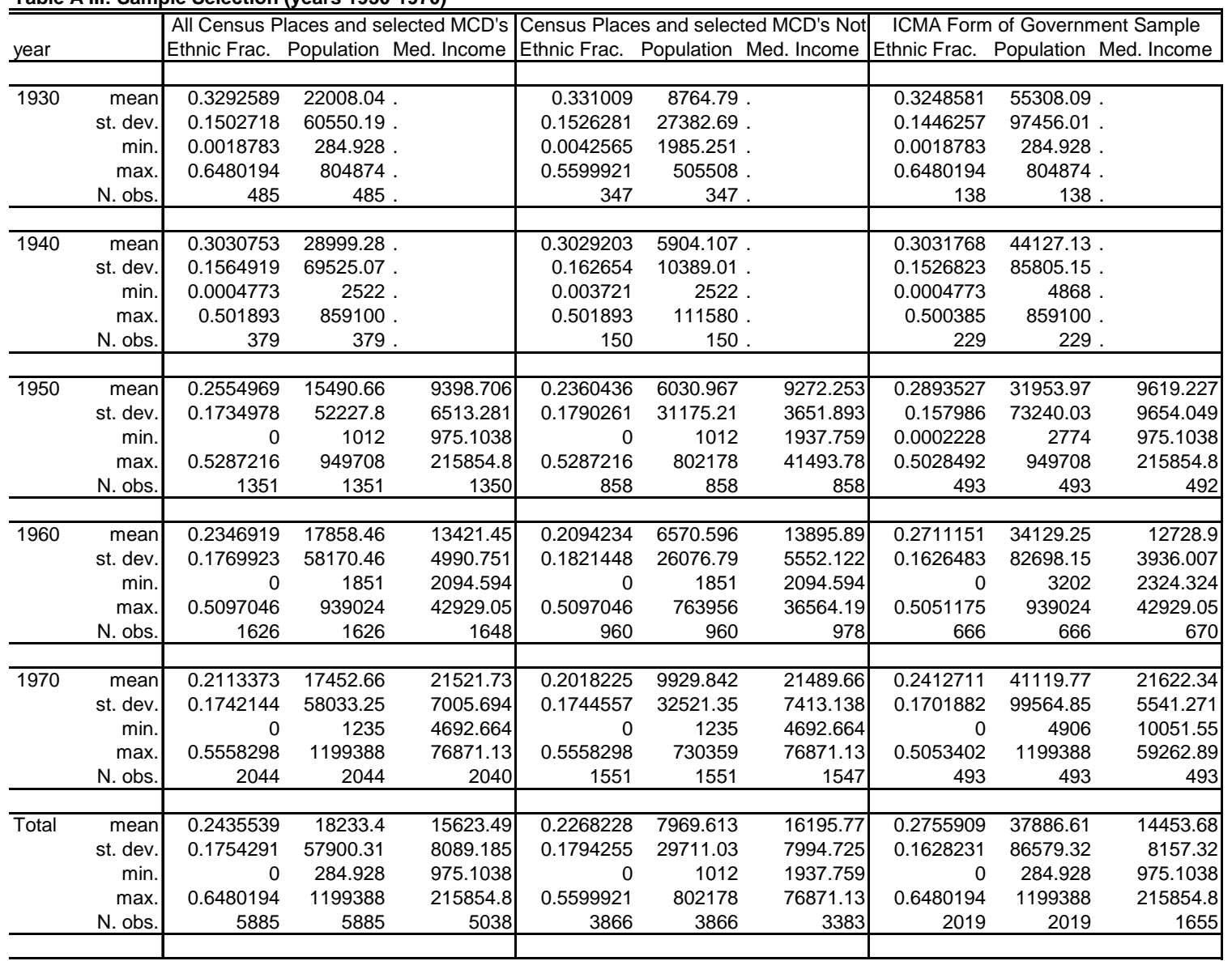

Note: The table includes only observations with non missing values. 